Prepared in cooperation with the Arkansas Natural Resources Commission and the Arkansas Geological Survey

\title{
Water-Level Trends and Potentiometric Surfaces in the Nacatoch Aquifer in Northeastern and Southwestern Arkansas and in the Tokio Aquifer in Southwestern Arkansas, 2014-15
}

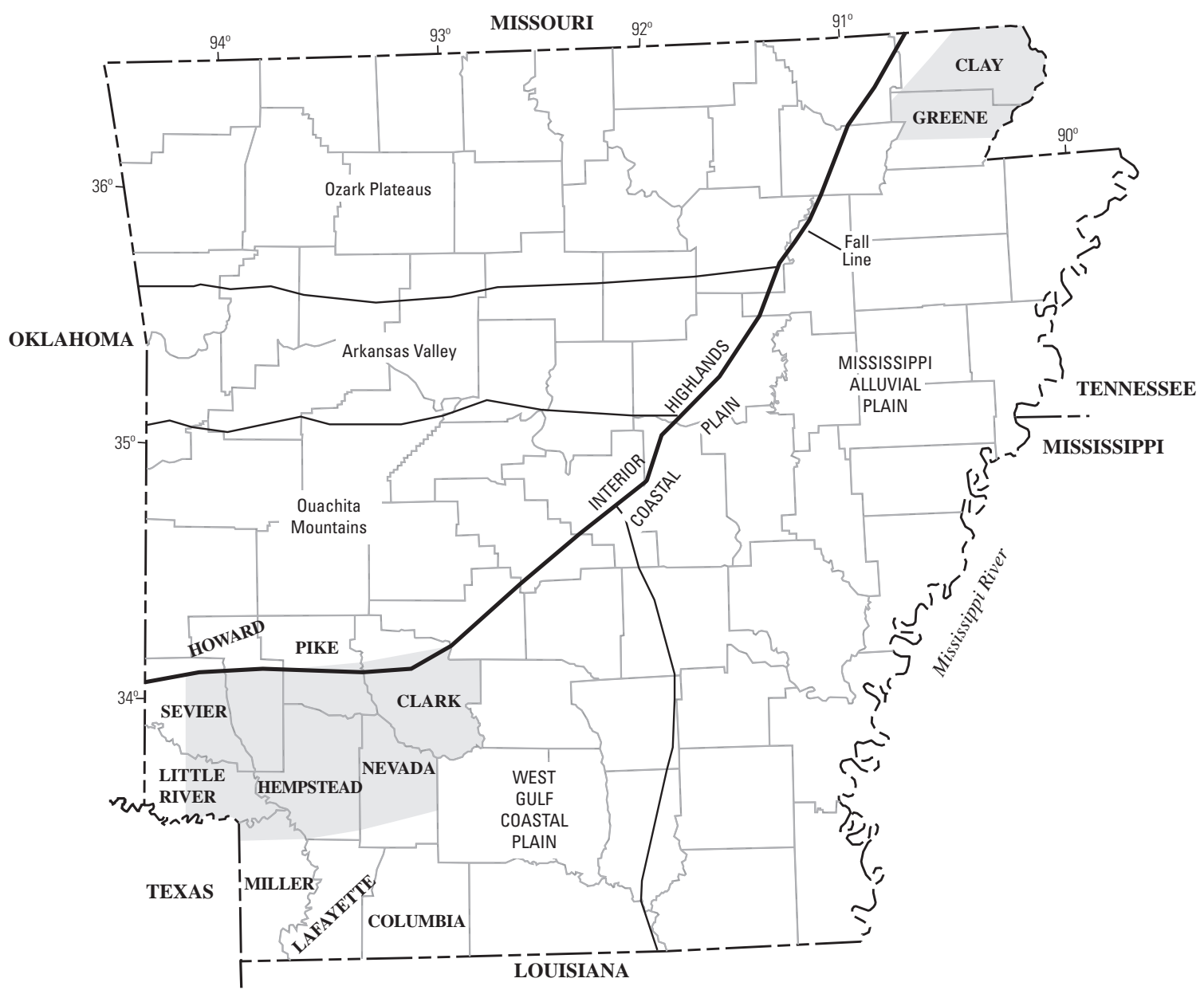

Scientific Investigations Report 2017-5090 



\section{Water-Level Trends and Potentiometric Surfaces in the Nacatoch Aquifer in Northeastern and Southwestern Arkansas and in the Tokio Aquifer in Southwestern Arkansas, 2014-15}

By Kirk D. Rodgers

Prepared in cooperation with the Arkansas Natural Resources Commission and the Arkansas Geological Survey

Scientific Investigations Report 2017-5090 


\title{
U.S. Department of the Interior \\ RYAN K. ZINKE, Secretary
}

\section{U.S. Geological Survey William H. Werkheiser, Acting Director}

\author{
U.S. Geological Survey, Reston, Virginia: 2017
}

For more information on the USGS - the Federal source for science about the Earth, its natural and living resources, natural hazards, and the environment—visit http://www.usgs.gov or call 1-888-ASK-USGS.

For an overview of USGS information products, including maps, imagery, and publications, visit http://www.usgs.gov/pubprod/.

Any use of trade, firm, or product names is for descriptive purposes only and does not imply endorsement by the U.S. Government.

Although this information product, for the most part, is in the public domain, it also may contain copyrighted materials as noted in the text. Permission to reproduce copyrighted items must be secured from the copyright owner.

Suggested citation:

Rodgers, K.D., 2017, Water-level trends and potentiometric surfaces in the Nacatoch aquifer in northeastern and southwestern Arkansas and in the Tokio aquifer in southwestern Arkansas, 2014-15: U.S. Geological Survey Scientific Investigations Report 2017-5090, 30 p., https://doi.org/10.3133/sir20175090.

ISSN 2328-0328 (online) 


\section{Contents}

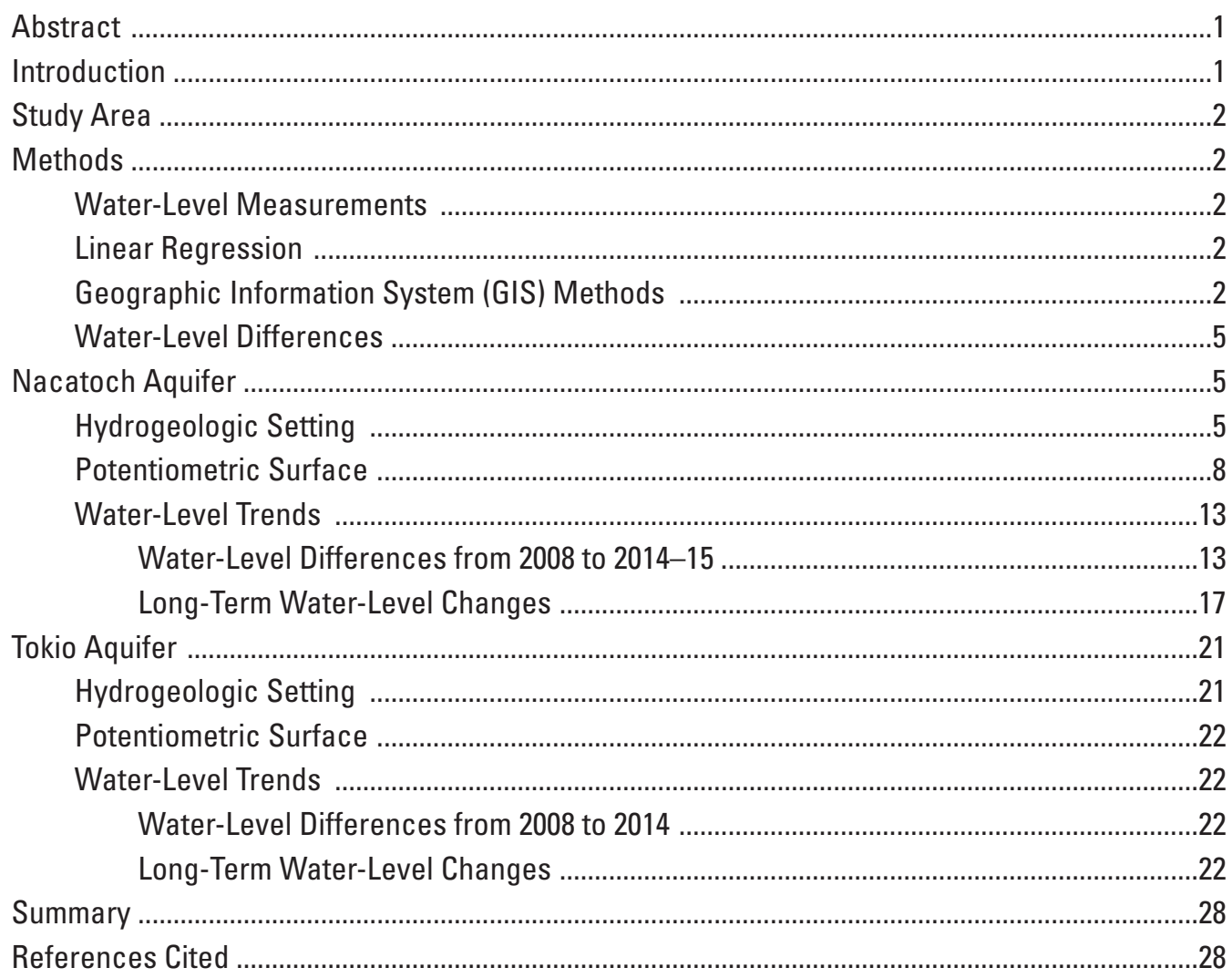

\section{Figures}

1. Map showing location of study areas in the Nacatoch aquifer in northeastern and southwestern Arkansas and the Tokio aquifer in southwestern Arkansas ...............3

2. Diagram showing well-numbering system ................................................................

3. Stratigraphic column and correlated hydrogeologic units of the Mississippi Embayment and West Gulf Coastal Plain physiographic region, Arkansas .....................6

4. Graph showing estimated withdrawals by county from the Nacatoch aquifer for the northeastern study area ......................................................................................

5. Graph showing estimated withdrawals by county from the Nacatoch aquifer for the southwestern study area ......................................................................................

6. Map showing potentiometric surface of the Nacatoch aquifer, northeastern Arkansas, 2015

7. Map showing potentiometric surface of the Nacatoch aquifer, southwestern Arkansas, 2014

8. Map showing water-level differences for the Nacatoch aquifer in northeastern Arkansas, 2008 to 2014-15

9. Map showing water-level differences for the Nacatoch aquifer in southwestern Arkansas, 2008 to 2014-15

10. Water-level hydrographs for selected wells completed in the Nacatoch aquifer in northeastern Arkansas 
11. Water-level hydrographs for selected wells completed in the Nacatoch aquifer in southwestern Arkansas

12. Graph showing estimated withdrawals by county from the Tokio aquifer for the southwestern study area

13. Map showing potentiometric surface of the Tokio aquifer in southwestern Arkansas, 2014

14. Map showing water-level differences for the Tokio aquifer in southwestern Arkansas, 2008-14

15. Water-level hydrographs for selected wells completed in the Tokio aquifer in southwestern Arkansas

\section{Tables}

1. Water-level data collected during 2014-15 from wells completed in the Nacatoch aquifer in northeastern and southwestern Arkansas

2. Difference in depth to water from 2008 to $2014-15$ in the Nacatoch aquifer in northeastern and southwestern Arkansas

3. Water-level data collected in 2014 from wells completed in the Tokio aquifer in southwestern Arkansas

4. Difference in depth to water from 2008 to 2014 in the Tokio aquifer in southwestern Arkansas

\section{Conversion Factors}

U.S. customary units to International System of Units

\begin{tabular}{lll}
\hline \multicolumn{1}{c}{ Multiply } & \multicolumn{1}{c}{ By } & To obtain \\
\hline & Length & \\
\hline foot (ft) & 0.3048 & meter $(\mathrm{m})$ \\
mile (mi) & 1.609 & kilometer $(\mathrm{km})$ \\
\hline & Flow rate & \\
\hline foot per year (ft/yr) & 0.3048 & meter per year $(\mathrm{m} / \mathrm{yr})$ \\
gallon per minute (gal/min) & 0.06309 & liter per second $(\mathrm{L} / \mathrm{s})$ \\
gallon per day (gal/d) & 0.003785 & cubic meter per day $\left(\mathrm{m}^{3} / \mathrm{d}\right)$ \\
million gallons per day (Mgal/d) & 0.04381 & cubic meter per second $\left(\mathrm{m}^{3} / \mathrm{s}\right)$ \\
\hline
\end{tabular}

\section{Datum}

Vertical coordinate information is referenced to the National Geodetic Vertical Datum of 1929 (NGVD 29).

Horizontal coordinate information is referenced to the North American Datum of 1983 (NAD 83).

Altitude, as used in this report, refers to distance above the vertical datum. 


\title{
Water-Level Trends and Potentiometric Surfaces in the Nacatoch Aquifer in Northeastern and Southwestern Arkansas and in the Tokio Aquifer in Southwestern Arkansas, 2014-15
}

\author{
By Kirk D. Rodgers
}

\section{Abstract}

The Nacatoch Sand in northeastern and southwestern Arkansas and the Tokio Formation in southwestern Arkansas are sources of groundwater for agricultural, domestic, industrial, and public use. Water-level altitudes measured in 51 wells completed in the Nacatoch Sand and 42 wells completed in the Tokio Formation during 2014 and 2015 were used to create potentiometric-surface maps of the two areas. Aquifers in the Nacatoch Sand and Tokio Formation are hereafter referred to as the Nacatoch aquifer and the Tokio aquifer, respectively.

Potentiometric surfaces show that groundwater in the Nacatoch aquifer flows southeast toward the Mississippi River in northeastern Arkansas. Groundwater flow direction is towards the south and southeast in Hempstead, Little River, and Nevada Counties in southwestern Arkansas. An apparent cone of depression exists in southern Clark County and likely alters groundwater flow from a regional direction toward the depression.

In southwestern Arkansas, potentiometric surfaces indicate that groundwater flow in the Tokio aquifer is towards the city of Hope. Northwest of Hope, an apparent cone of depression exists. In southwestern Pike, northwestern Nevada, and northeastern Hempstead Counties, an area of artesian flow (water levels are at or above land surface) exists.

Water-level changes in wells were identified using two methods: (1) linear regression analysis of hydrographs from select wells with a minimum of 20 years of waterlevel data, and (2) a direct comparison between waterlevel measurements from 2008 and 2014-15 at each well. Of the six hydrographs analyzed in the Nacatoch aquifer, four indicated a decline in water levels. Compared to 2008 measurements, the largest rise in water levels was 35.14 feet (ft) in a well in Clark County, whereas the largest decline was $14.76 \mathrm{ft}$ in a well in Nevada County, both located in southwestern Arkansas.
Of the four hydrographs analyzed in the Tokio aquifer, one indicated a decline in water levels, while the others remained relatively unchanged. Compared to 2008 measurements, the largest rise in water levels was $21.34 \mathrm{ft}$ in Hempstead County, and the largest water-level decline was $39.37 \mathrm{ft}$ in Clark County. Although changes in water levels since 2008 are spatially varied; long-term trends indicate an overall decline in water levels in both aquifers.

\section{Introduction}

As a renewable resource, groundwater is important for economic growth and quality of life. Monitoring of groundwater levels and withdrawals provides information needed to effectively plan and manage this renewable resource. Groundwater in Arkansas is used for agricultural, domestic, industrial, and public use. Groundwater resources have been subjected to increasing withdrawals for many years, raising concerns that water levels will not rebound to previous levels. The withdrawals from the Nacatoch aquifer occur in northeastern and southwestern Arkansas and from the Tokio aquifer in southwestern Arkansas.

As part of groundwater monitoring efforts, a study was conducted by the U.S. Geological Survey (USGS) in cooperation with the Arkansas Natural Resources Commission and the Arkansas Geological Survey to measure water levels and to present the data as potentiometric-surface maps, waterlevel difference maps, and long-term water-level hydrographs for wells screened in the Nacatoch aquifer in northeastern and southwestern Arkansas and the Tokio aquifer in southwestern Arkansas. Potentiometric-surface maps were created from measurements made in 51 wells completed in the Nacatoch aquifer and in 42 wells completed in the Tokio aquifer during 2014 and 2015. Water-level difference maps, long-term water-level hydrographs for selected wells, and groundwaterwithdrawal data from 1965 to 2010 were prepared for this report. 


\section{Study Area}

The study areas of the Nacatoch and Tokio aquifers comprise parts of 10 counties in two areas of northeastern and southwestern Arkansas. The Nacatoch aquifer is divided into two study areas. The northeastern study area includes most of Clay and Greene Counties in the Mississippi Alluvial Plain physiographic section (fig. 1). This area is bounded on the north and east by the Missouri State line and on the west by the western extent of the aquifer. The southern boundary of this area is defined by the southern extent of water withdrawals from wells screened in the aquifer. The southwestern study area includes parts of eight counties (Clark, Hempstead, Howard, Little River, Miller, Nevada, Pike, and Sevier) in the West Gulf Coastal Plain physiographic region (fig. 1).

The Tokio aquifer study area covers the same counties as the southwestern Nacatoch aquifer. This area is bounded on the north by the Fall Line separating the Interior Highlands from the West Gulf Coastal Plain, on the west by the extent of use and the availability of wells, and on the east by the eastern borders of Clark and Nevada Counties. The southern boundary of the southwestern study area coincides with a freshwater-saltwater interface. To the south of this interface, the groundwater is considered saline (more than 1,000 milligrams per liter of dissolved solids) and is not suitable for most uses (Boswell and others, 1965; Petersen and others, 1985).

\section{Methods}

\section{Water-Level Measurements}

Water levels were measured by USGS personnel during 2014-15 in wells screened in the Nacatoch and Tokio aquifers. Measurements were made with electric or steel tapes graduated to hundredths of a foot. The tapes were calibrated during January 2014 and January 2015 prior to data collection. Calibration of electric and steel tapes was performed by comparing the tapes to a standardized steel tape used only for calibration (Cunningham and Schalk, 2011). All water-level data are stored in the USGS Groundwater Site Inventory (GWSI) data storage system and are publicly available from the USGS National Water Information System (NWIS) (U.S. Geological Survey, 2016).

Well locations were measured using Global Positioning System receivers to acquire the horizontal coordinate information (latitude and longitude) based upon the North American Datum of 1983 (NAD 83). Land-surface altitude, measured in feet above National Geodetic Vertical Datum of 1929 (NGVD 29), was determined for each well by superposition of the latitude and longitude of the well on a USGS topographic map and is accurate to about one-half the topographic contour interval of 5 to 10 feet (ft). Herein, all water-level and land-surface altitudes are referenced to NGVD 29. Mapped altitudes for flowing artesian wells represent the pressure head of the water within the well.

The well-numbering system used in this report is based upon the location of the wells according to the Public Land Survey System. The component parts of a well number are the township number and direction; the range number and direction; the section number; and three letters that indicate, respectively, the quarter section, quarter-quarter section, and the quarter-quarter-quarter section in which the well is located; and a sequence number of the well in the quarter-quarterquarter section. The letters are assigned counterclockwise, beginning with " $\mathrm{A}$ " in the northeast quarter, quarter-quarter, or quarter-quarter-quarter section. For example, well 01S03W04BBD16 (fig. 2) is located in Township 1 South, Range 3 West, and in the southeast quarter of the northwest quarter of the northwest quarter of section 4 . This well is the 16th well in the quarter-quarter-quarter section of section 4 from which data were collected.

\section{Linear Regression}

Linear regression analysis was used to determine the annual rise or decline of water levels in selected wells using the well hydrograph. Water-level measurements made yearly during February, March, and April of the minimum 20-year period of record were used in the linear regression analysis. A 20-year minimum period of analysis reduces the effect of localized short-term pumping rates and variations in climate on water levels in a single well. The equation of the regression line or line of best fit is $\mathrm{Y}=\mathrm{MX}+\mathrm{B}$. The slope, $\mathrm{M}$ from the equation, represents the daily rise or decline in water level; $\mathrm{B}$ is the water level measured in feet where the line intersects the $\mathrm{y}$-axis; $\mathrm{X}$ is time, in years; and $\mathrm{Y}$ is the water level, in feet above NGVD 29. Five assumptions are associated with linear regression: (1) Y is linearly related to $\mathrm{X}$, (2) data used to fit the linear regression are representative of data of interest, (3) variance of the residuals is constant and does not depend on X or on anything else, (4) the residuals are independent, and (5) the residuals are normally distributed. The assumption of a normal distribution is involved only when testing hypotheses, requiring the residuals from the regression equation to be normally distributed (Helsel and Hirsch, 2002).

\section{Geographic Information System (GIS) Methods}

Longitude and latitude of wells were obtained from NWIS and encoded using ArcGIS (Esri, 2011). The encoded data points were used to create potentiometric maps of the Nacatoch and Tokio aquifers by interpolation. This process produces a raster image that assigns a range of values to each color in the image. The image is then 


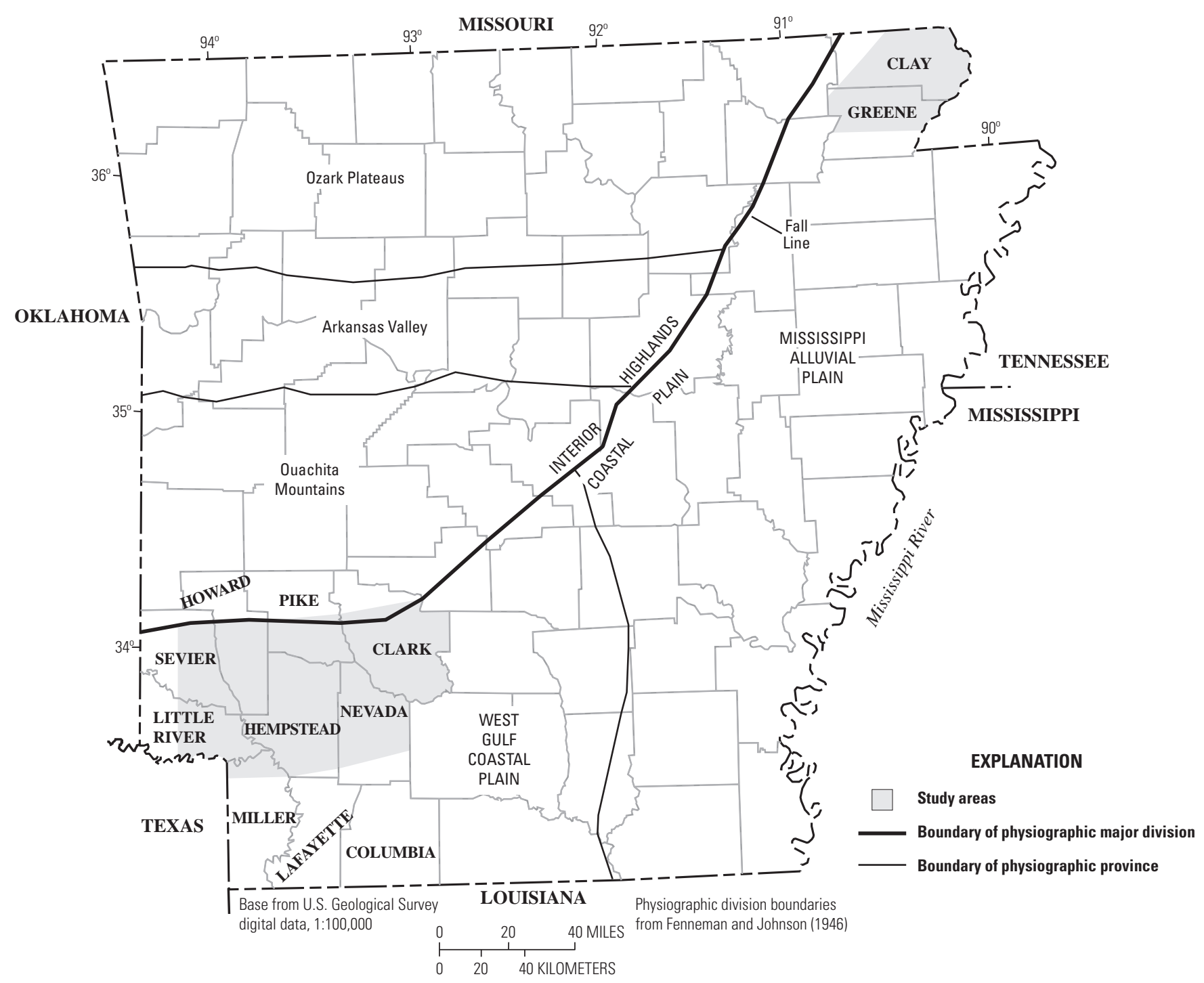

Figure 1. Location of study areas in the Nacatoch aquifer in northeastern and southwestern Arkansas and the Tokio aquifer in southwestern Arkansas. 


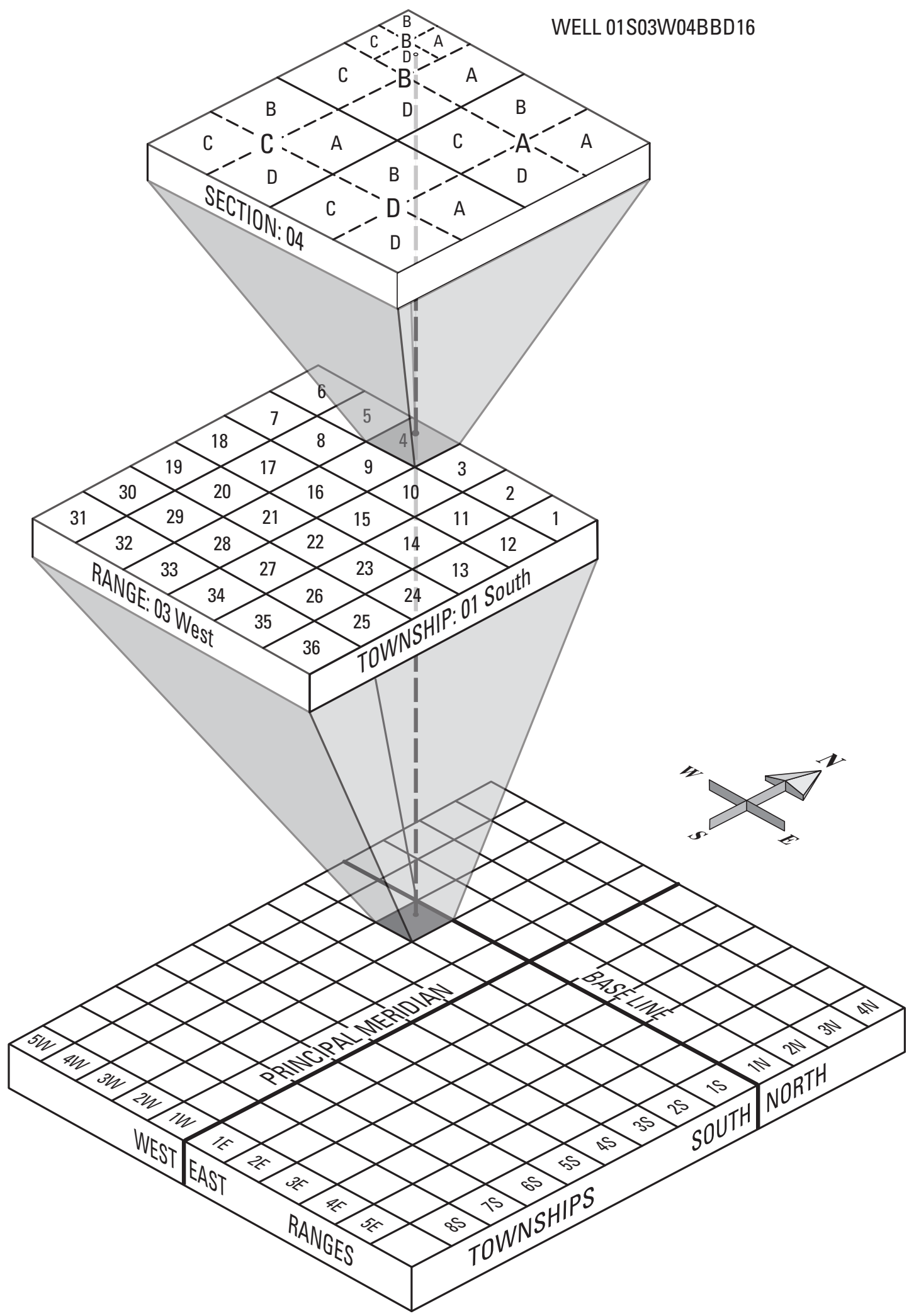

Figure 2. Well-numbering system. 
converted to contour polylines using the raster-to-contour tool. Upon conversion, the contour polylines were corrected and refined using the Polynomial Approximation with Exponential Kernel (PEAK) method of smoothing, which allows for the preservation of endpoints. This algorithm uses the maximum allowable offset to smooth lines (Bodansky and others, 2002) and sets a tolerance by which lines are smoothed. A higher tolerance preserves less detail from the original interpolated contour line, and a lower tolerance preserves more detail. A 0.075-decimal degree tolerance was used to smooth the contour lines and to preserve more detail of the original potentiometric contour polylines. All GIS data used to create maps interpreted in this report can be found at Rodgers (2017).

\section{Water-Level Differences}

Water-level difference maps for wells screened in the Nacatoch aquifer in northeastern and southwestern Arkansas and the Tokio aquifer in southwestern Arkansas were created to spatially evaluate short-term (6-7 years) change in water levels. The maps were created using the difference between water-level measurements made in 2008 and 2014-15 for the Nacatoch aquifer and between 2008 and 2014 for the Tokio aquifer. Positive values indicated a rise in water levels; negative values indicated a decline in water levels.

\section{Nacatoch Aquifer}

\section{Hydrogeologic Setting}

The Nacatoch Sand of Late Cretaceous age comprises the Nacatoch aquifer and is underlain by the Saratoga Chalk and overlain by the Arkadelphia Marl (fig. 3). In the northeastern study area, the Nacatoch Sand subcrops beneath Quaternary alluvial and terrace deposits at its western extent. The altitude of the top of the Nacatoch Sand ranges from 50 to $100 \mathrm{ft}$ above NGVD 29 along the western boundary and dips southeasterly to 1,200 ft below NGVD 29 at the Mississippi River. Petersen and others (1985) found this unit to be approximately $100 \mathrm{ft}$ in thickness at the subcrop and increasing to near $600 \mathrm{ft}$ at the downdip extent of the formation.

In the northeastern study area, the aquifer is composed of fine sand, interbedded clay and limestone in the lower part, and increases in grade to loose fine quartz sand in the upper part (Petersen and others, 1985). In western Clay and Greene Counties, the aquifer is recharged by precipitation through its outcrop and subcrop areas (Petersen and others, 1985).

In the southwestern study area, the aquifer crops out in a 3- to 8-mile (mi) wide belt from central Clark County that extends southwesterly toward western Hempstead County.
In Little River County, the aquifer subcrops beneath alluvial and terrace deposits (Boswell and others, 1965). The highest altitude in the southwestern study area is approximately 300 $\mathrm{ft}$ above NGVD 29 in the outcrop and descends southeasterly to about $800 \mathrm{ft}$ below NGVD 29 at the southern extent of the study area. At the outcrop, the Nacatoch Sand is about $100 \mathrm{ft}$ thick and has a maximum thickness of $600 \mathrm{ft}$ (Petersen and others, 1985).

In the southwestern study area, the Nacatoch Sand is composed of three distinct units. The lower unit contains interbedded gray clay, sandy clay and marl, dark clayey fine-grained sand, and hard irregular concretionary beds with lenses of slightly glauconitic, calcareous, fossiliferous sand (Plebuch and Hines, 1969). The middle unit is composed of dark-green sand with coarse glauconite grains. The unit is fossiliferous where it is glauconitic and contains irregular concretionary beds (Plebuch and Hines, 1969). The upper unit is the primary water-bearing unit (Counts and others, 1955; Plebuch and Hines, 1969; Ludwig, 1972; Kresse and others, 2014) and consists of gray, fine-grained, unconsolidated quartz sand that is commonly cross-bedded. The sand has a few locally hard lenses, is massive, and has beds of fossiliferous, sandy limestone.

Recharge of the Nacatoch aquifer in the southwestern study area occurs by precipitation in the outcrop in Clark, Hempstead, and Nevada Counties and through alluvium and terrace deposits in Little River County. The aquifer supplies water to northeastern Clay and Greene Counties, southern Clark County, central Hempstead County, southeastern Little River County, northern Miller County, and northwestern Nevada County.

In the valleys of Clark and Nevada Counties, artesian wells within the Nacatoch aquifer can yield from 1 to 2 gallons per minute (gal/min). Wells in Hempstead and western Nevada Counties can yield 150 to $300 \mathrm{gal} / \mathrm{min}$ (Counts and others, 1955). Groundwater flow in general is to the southeast, but an increase in clay content in the downdip direction in Lafayette, Miller, and Nevada Counties may influence flow direction. A well test in the aquifer at Hope indicated a transmissivity of 3,600 gallons per day per foot (Ludwig, 1972).

Estimated withdrawals from the Nacatoch aquifer in the northeastern study area rose 564 percent from 0.25 million gallons per day (Mgal/d) in 1965 to $1.66 \mathrm{Mgal} / \mathrm{d}$ in 2010, with a maximum usage of 2.21 Mgal/d in 1990 (fig. 4; Holland, 1993, 1999, 2004, 2007; Schrader and Rodgers, 2013; Pugh and Holland, 2015). Withdrawals from the southwestern study area reached a peak of $4.75 \mathrm{Mgal} / \mathrm{d}$ in 1980 (fig. 5) and declined by 85 percent to less than $1 \mathrm{Mgal} / \mathrm{d}$ by 2010. This decline has been attributed to public water supplies converting to surface-water sources and relying less on groundwater sources (Holland and Ludwig, 1981; Holland, 1987, 1993, 1999, 2004, 2007; Schrader and Rodgers, 2013). Withdrawal data from the aquifer were not reported for several counties and appear as $0.00 \mathrm{Mgal} / \mathrm{d}$ in the record. 
Water-Level Trends and Potentiometric Surfaces in the Nacatoch Aquifer and in the Tokio Aquifer, Arkansas

\begin{tabular}{|c|c|c|c|c|c|c|}
\hline \multicolumn{4}{|c|}{ Time-stratigraphic unit } & \multirow{2}{*}{\multicolumn{2}{|c|}{ Formation }} & \multirow{2}{*}{ Regional geohydrologic unit } \\
\hline Era & System & Series & Group & & & \\
\hline \multirow{10}{*}{ Cenozoic } & \multirow[b]{2}{*}{ Quaternary } & Holocene & & \multicolumn{2}{|l|}{ Alluvium } & \multirow{2}{*}{$\begin{array}{l}\text { Mississippi River Valley alluvial aquifer } \\
\text { Ouachita-Saline River alluvial aquifer }{ }^{2} \\
\text { Red River alluvial aquifer }{ }^{2}\end{array}$} \\
\hline & & Pleistocene & & \multicolumn{2}{|c|}{ Terrace deposits } & \\
\hline & \multirow{8}{*}{ Tertiary } & \multirow{7}{*}{ Eocene } & Jackson & \multicolumn{2}{|c|}{ Jackson Formation } & Vicksburg-Jackson confining unit ${ }^{1}$ \\
\hline & & & \multirow{5}{*}{ Claiborne } & \multicolumn{2}{|c|}{ Cockfield Formation } & Upper Claiborne aquifer ${ }^{1}$ \\
\hline & & & & \multicolumn{2}{|c|}{ Cook Mountain Formation } & Middle Claiborne confining unit \\
\hline & & & & Sparta Sand & \multirow{3}{*}{$\begin{array}{l}\text { Memphis } \\
\text { Sand }^{3}\end{array}$} & Middle Claiborne aquifer ${ }^{1}$ \\
\hline & & & & $\begin{array}{l}\text { Cane River } \\
\text { Formation }\end{array}$ & & Lower Claiborne $^{1}$ \\
\hline & & & & Carrizo Sand & & Lower Claiborne confining unit ${ }^{1}$ \\
\hline & & & Wilcox & \multicolumn{2}{|c|}{ Undifferentiated } & Middle - Lower Wilcox aquifer ${ }^{1}$ \\
\hline & & Paleocene & Midway & \multicolumn{2}{|c|}{$\begin{array}{l}\text { Porters Creek Clay } \\
\text { Clayton Formation }\end{array}$} & Midway confining unit ${ }^{1}$ \\
\hline \multirow{11}{*}{ Mesozoic } & \multirow{11}{*}{ Cretaceous } & \multirow{9}{*}{$\begin{array}{l}\text { Upper } \\
\text { Cretaceous }\end{array}$} & & \multicolumn{2}{|c|}{ Arkadelphia Marl } & \\
\hline & & & & \multicolumn{2}{|c|}{ Nacatoch Sand } & Nacatoch aquifer ${ }^{2}$ \\
\hline & & & & \multicolumn{2}{|c|}{ Saratoga Chalk } & \\
\hline & & & & \multicolumn{2}{|c|}{ Marlbrook Marl } & \\
\hline & & & & \multicolumn{2}{|c|}{ Annona Chalk } & \\
\hline & & & & \multicolumn{2}{|c|}{ Ozan Formation } & \\
\hline & & & & \multicolumn{2}{|c|}{ Brownstown Marl } & \\
\hline & & & & \multicolumn{2}{|c|}{ Tokio Formation } & \multirow{2}{*}{ Tokio aquifer ${ }^{2}$} \\
\hline & & & & \multicolumn{2}{|c|}{ Woodbine Formation } & \\
\hline & & & & \multicolumn{2}{|c|}{$\begin{array}{l}\text { Kiamichi Formation } \\
\text { Goodland Limestone }\end{array}$} & \\
\hline & & $\begin{array}{l}\text { Lower } \\
\text { Cretaceous }\end{array}$ & Trinity & $\begin{array}{l}\text { Paluxy Form } \\
\text { DeQueen Lir } \\
\text { Holly Creek } \\
\text { Dierks Limes } \\
\text { Delight Sand } \\
\text { Pike Gravel }\end{array}$ & $\begin{array}{l}\text { ne } \\
\text { ation }\end{array}$ & Trinity aquifer ${ }^{2}$ \\
\hline
\end{tabular}

${ }^{1}$ From Hart and others, 2008.

${ }^{2}$ From Renken, 1998.

${ }^{3}$ North of $35^{\circ} \mathrm{N}$ latitude, the Sparta Sand, Cane River Formation, and Carrizo Sand are undifferentiated and referred to regionally as the Memphis Sand (Counts, 1957; Cushing and others, 1964; Payne, 1972; Petersen and others, 1985; Hart and others, 2008).

Figure 3. Stratigraphic column and correlated hydrogeologic units of the Mississippi Embayment and West Gulf Coastal Plain physiographic region, Arkansas. 


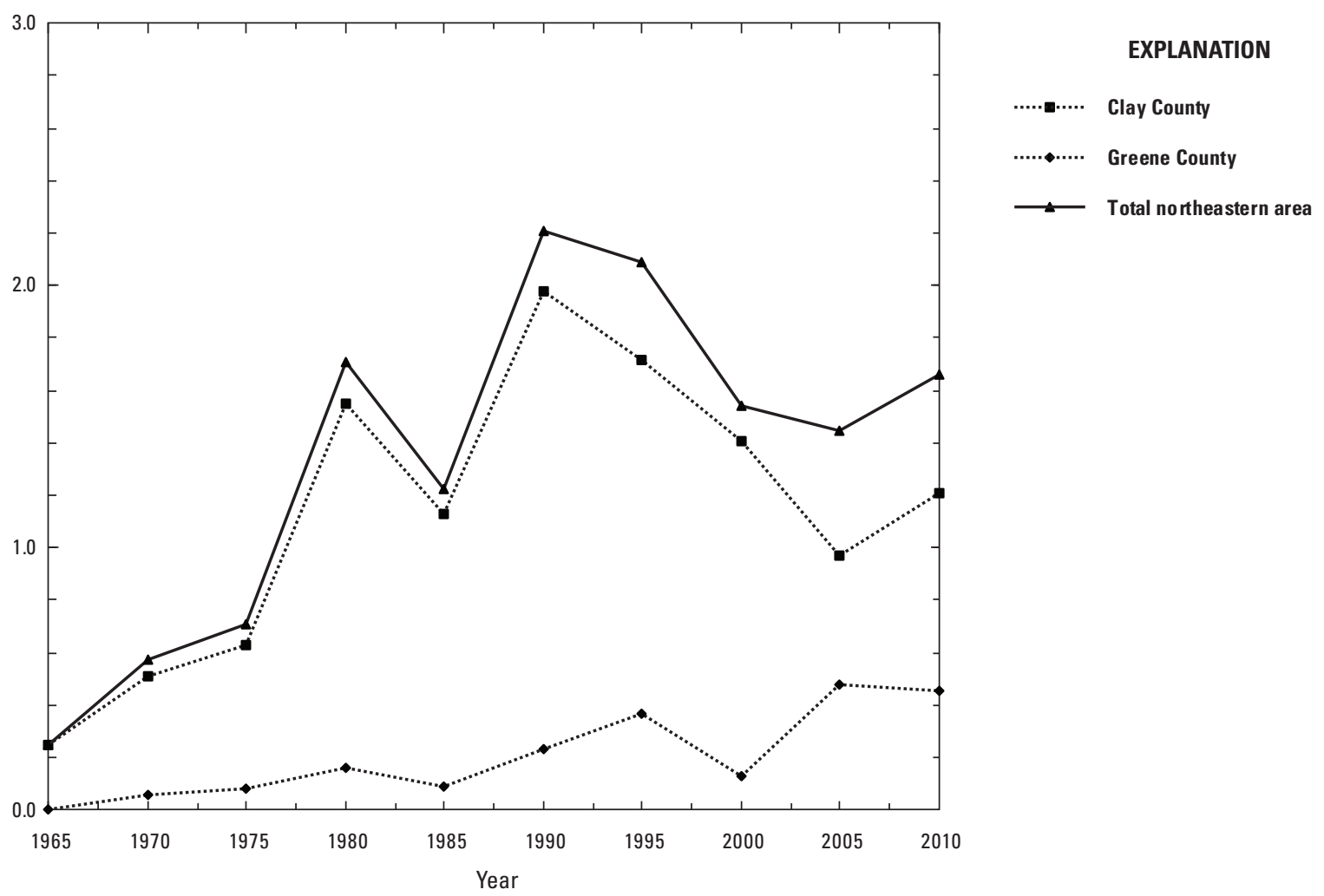

Figure 4. Estimated withdrawals by county from the Nacatoch aquifer for the northeastern study area.

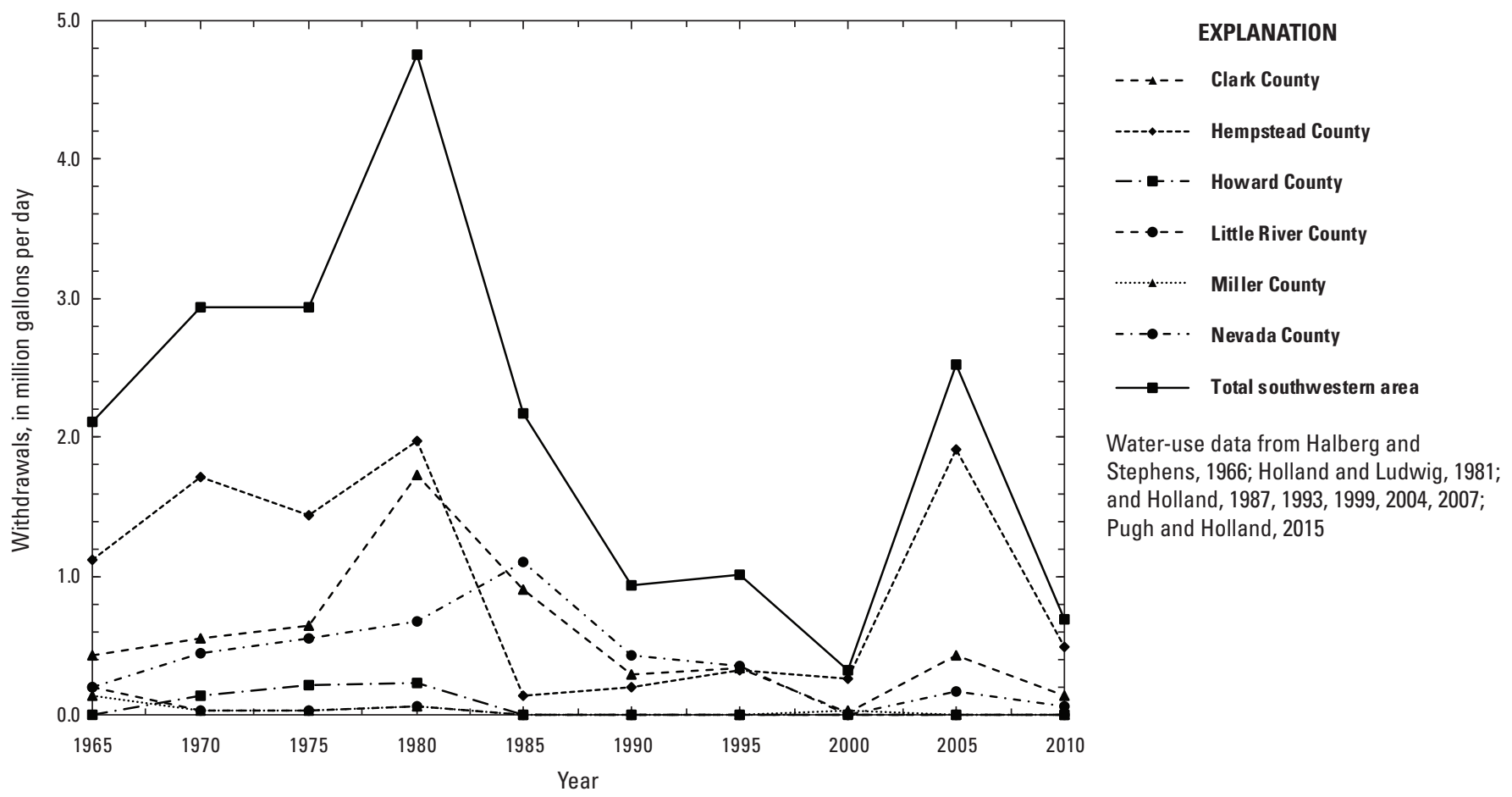

Figure 5. Estimated withdrawals by county from the Nacatoch aquifer for the southwestern study area. 


\section{Potentiometric Surface}

In the northeastern study area (fig. 6), groundwater flows southeasterly toward the Mississippi River from a potentiometric high of $275 \mathrm{ft}$ above NGVD 29 in northcentral Clay County to a potentiometric low of $230 \mathrm{ft}$ above NGVD 29 in northeastern Greene County (table 1). The direction of groundwater flow has not changed since the 2013 potentiometric mapping of the northeastern Nacatoch aquifer (Schrader and Rodgers, 2013).

The direction of groundwater flow varies in the southwestern study area. In Hempstead, Little River, and Nevada Counties, groundwater flow is towards the south and southeast (fig. 7). In Clark County, groundwater flow is towards the east and southeast. In western Miller County, groundwater flows north toward the Red River from a water-level altitude of $293 \mathrm{ft}$ above NGVD 29. The highest water-level altitude measured was $423 \mathrm{ft}$ above NGVD 29 in the outcrop area of the Nacatoch aquifer in western Hempstead County. A water-level altitude of 160 $\mathrm{ft}$ was measured near Hope in southern Hempstead County, indicating a cone of depression may exist (fig. 7). Water levels in wells near the Hope area have been less than $185 \mathrm{ft}$ above NGVD 29 since at least 1942 (Ludwig, 1972; Schrader and Scheiderer, 2004). The apparent cone of depression alters groundwater flow from the regional direction with groundwater flowing from the north, northeast, and west toward Hope. Another cone of depression exists in southern Clark County and is probably drawdown related to public supply use in the area. All data in support of this report can be accessed from the USGS NWIS (U.S. Geological Survey, 2016). 


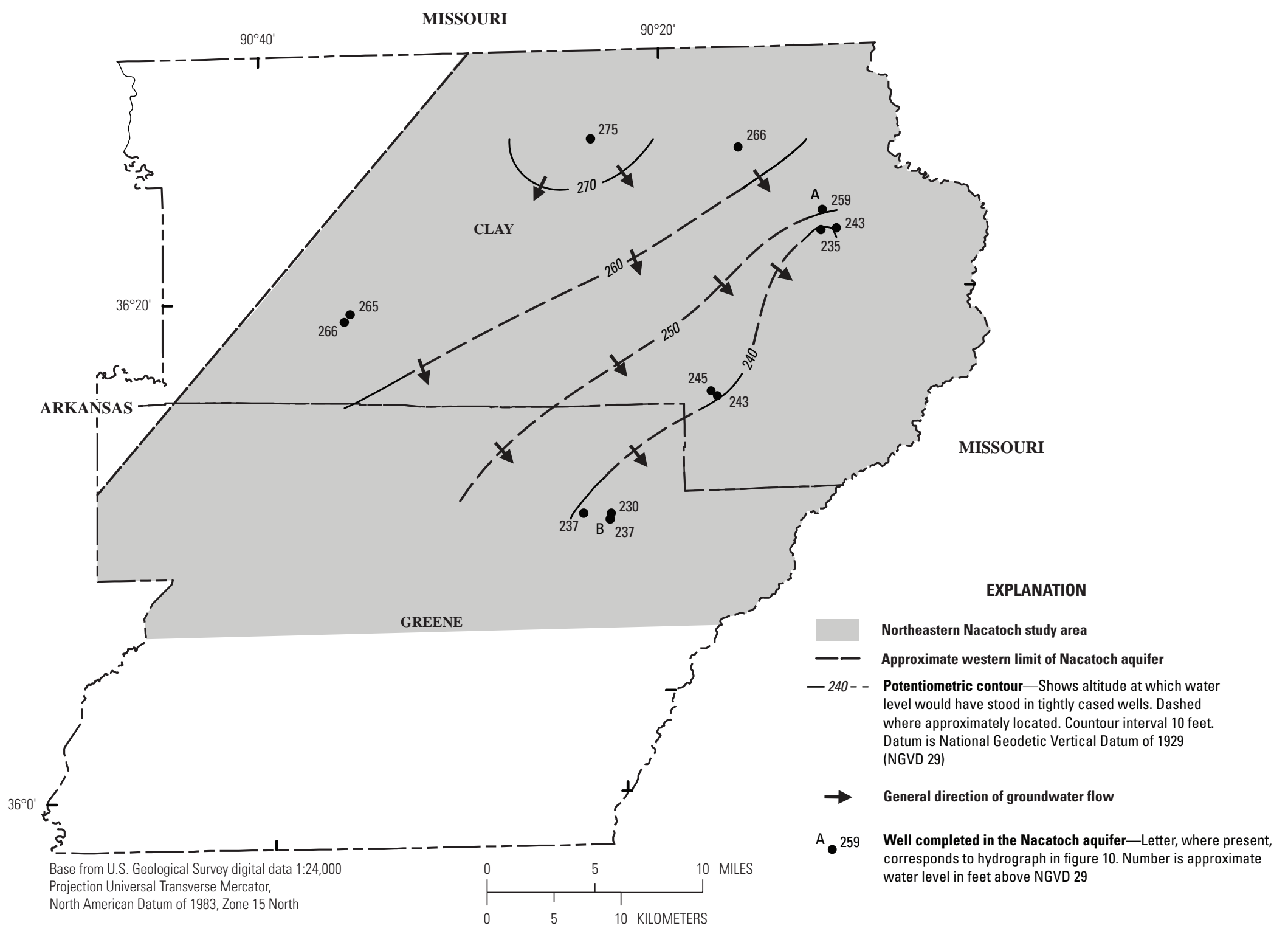

Figure 6. Potentiometric surface of the Nacatoch aquifer, northeastern Arkansas, 2015. 


\section{Water-Level Trends and Potentiometric Surfaces in the Nacatoch Aquifer and in the Tokio Aquifer, Arkansas}

Table 1. Water-level data collected during 2014-15 from wells completed in the Nacatoch aquifer in northeastern and southwestern Arkansas.

[Horizontal datum is North America Datum of 1983; Vertical datum is referenced to the National Geodetic Vertical Datum of 1929 (NGVD 29 ); letters in parentheses correspond to well locations in figures 6 and 7 and well hydrographs in figures 10 and 11; values rounded to the nearest whole number]

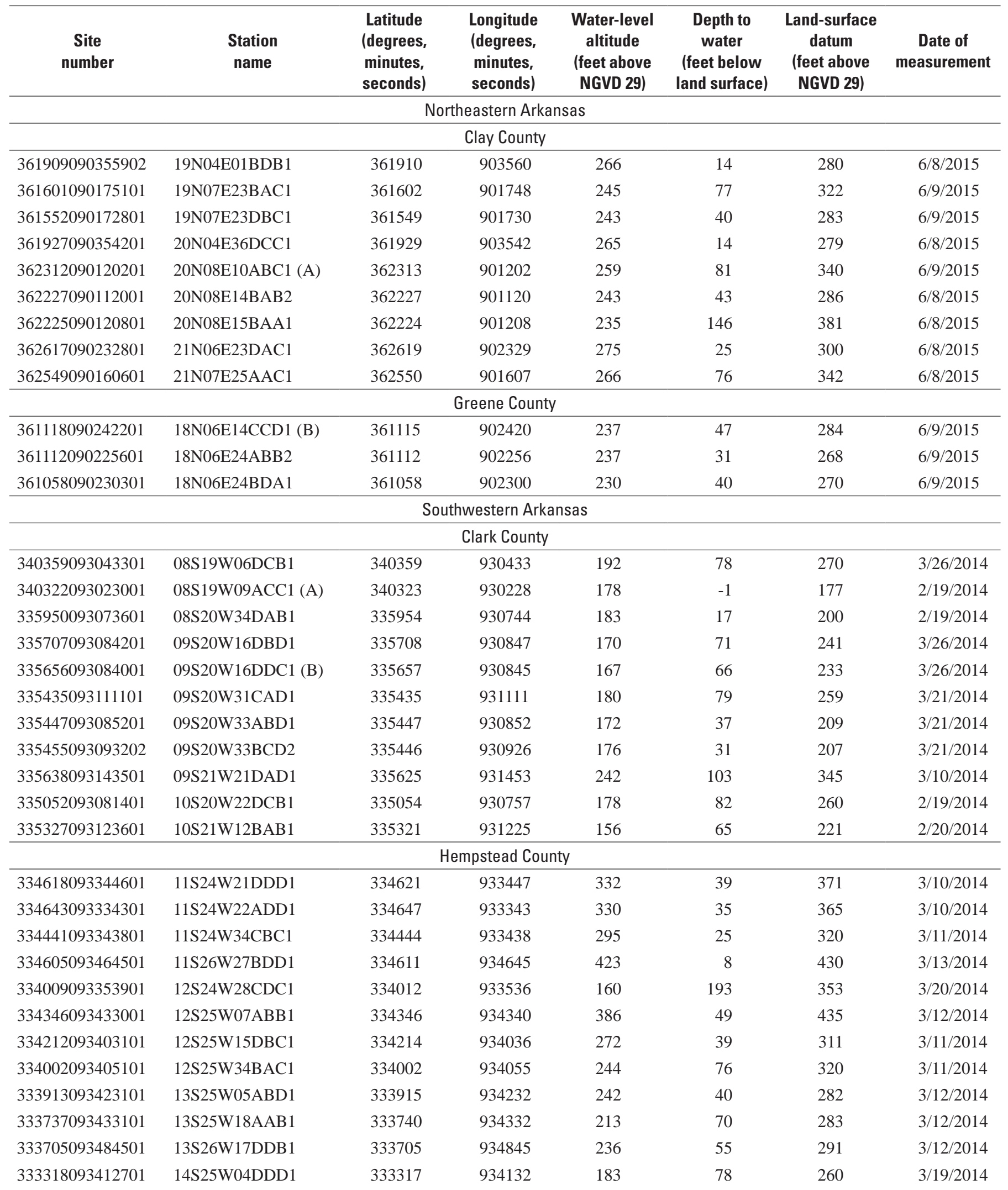


Table 1. Water-level data collected during 2014-15 from wells completed in the Nacatoch aquifer in northeastern and southwestern Arkansas.-Continued

[Horizontal datum is North America Datum of 1983; Vertical datum is referenced to the National Geodetic Vertical Datum of 1929 (NGVD 29 ); letters in parentheses correspond to well locations in figures 6 and 7 and well hydrographs in figures 10 and 11; values rounded to the nearest whole number]

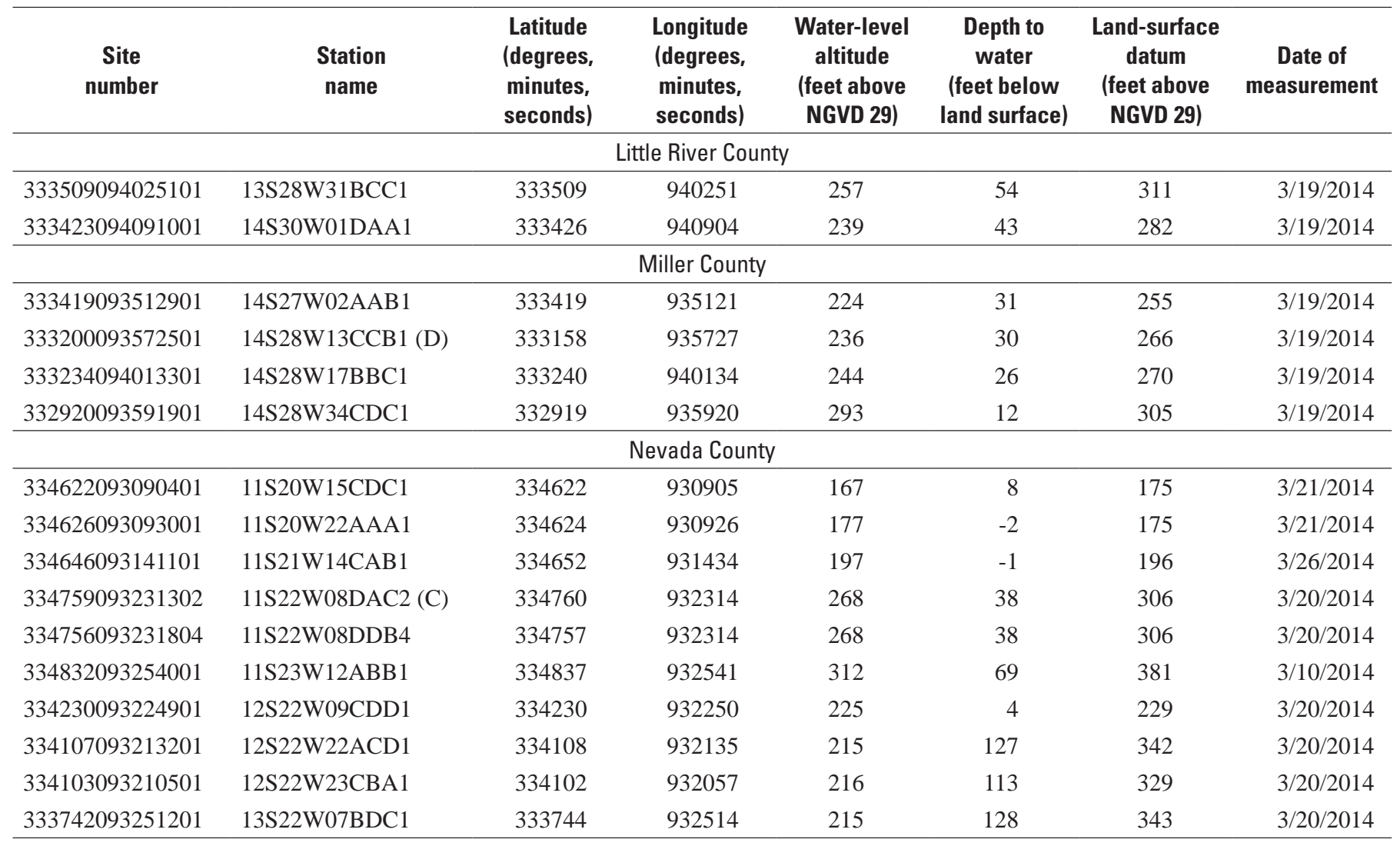




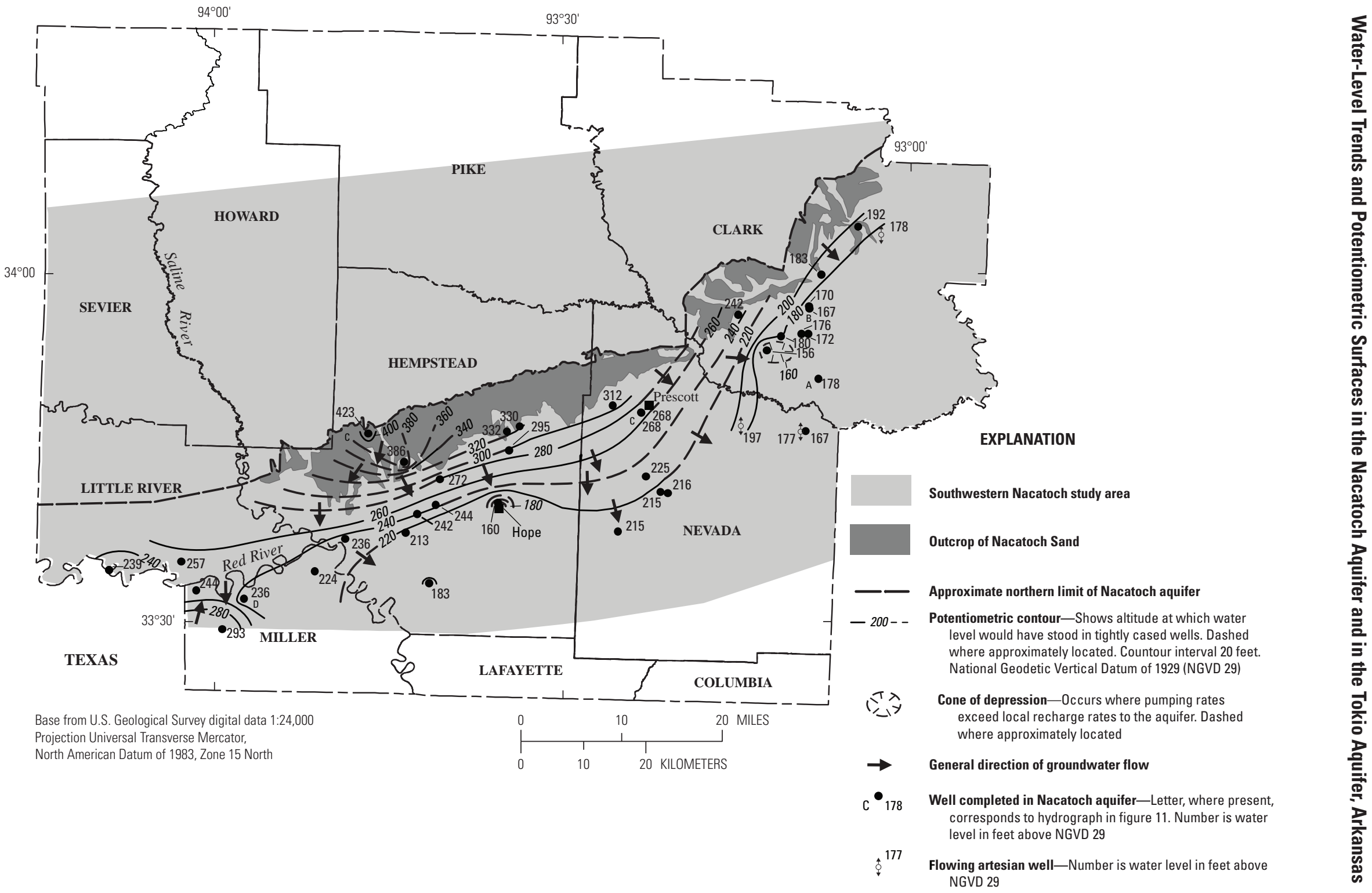

Figure 7. Potentiometric surface of the Nacatoch aquifer, southwestern Arkansas, 2014. 


\section{Water-Level Trends}

\section{Water-Level Differences from 2008 to 2014-15}

Water levels rose in 29 of the 51 measured wells in the Nacatoch aquifer (table 2). Differences in water levels in the two study areas ranged from a rise of $35.14 \mathrm{ft}$ in Clark County to a decline of $14.76 \mathrm{ft}$ in Nevada County, both located in southwestern Arkansas. In the northeastern study area, water levels generally have risen since 2008 (fig. 8). In Clay County, water-level changes ranged between a decline of $3.27 \mathrm{ft}$ in well 21N07E25AAC1 and a rise of $7.62 \mathrm{ft}$ in well 20N08E10ABC1 (table 2). In Greene County, water-level changes ranged from a decline of $0.19 \mathrm{ft}$ to a rise of $3.87 \mathrm{ft}$.

In the southwestern study area, water levels rose in 21 of the 39 wells measured (fig. 9). However, water-level changes varied by county. For example, water levels generally rose in Clark and Nevada Counties, and there was a general decline in Hempstead and Miller Counties. Although an apparent cone of depression exists in southern Clark County, water levels have been on the rise since 2002 (146 ft above NGVD 29 in 2002 [Schrader and Scheiderer, 2004]; $152 \mathrm{ft}$ above NGVD 29 in 2011 [Schrader and Rodgers, 2013]; and $156 \mathrm{ft}$ above NGVD 29 in 2014). Water-level changes in other wells screened in the aquifer are minor in comparison to those published in previous studies. The largest rise in water levels (35.14 ft) was in Clark County well 09S20W31CAD1, whereas the largest decline in water levels (14.76 ft) was in Nevada County well 11S22W08DDB4.

In Hempstead County, the highest rise (28.44 ft) was found in the southern part of the county (well 14S25W04DDD1), and the largest decline (14.09 ft) was found in the south-central part of the county (well 13S25W05ABD1). Of the four wells measured in Miller County, water levels declined in three wells. The largest decline (9.52 ft) was found in northeastern Miller County well 14S28W34CDC1. Of the wells measured in the southwestern study area, three were artesian wells.

Table 2. Difference in depth to water from 2008 to 2014-15 in the Nacatoch aquifer in northeastern and southwestern Arkansas.

[Horizontal datum is North American Datum of 1983; Vertical datum is referenced to the National Geodetic Vertical Datum of 1929 (NGVD 29); positive values for water-level difference indicate a rise in water levels from 2008 to 2014-15 whereas negative values for water-level difference indicate a decline in water levels from 2008 to $2014-15$; --, no data available]

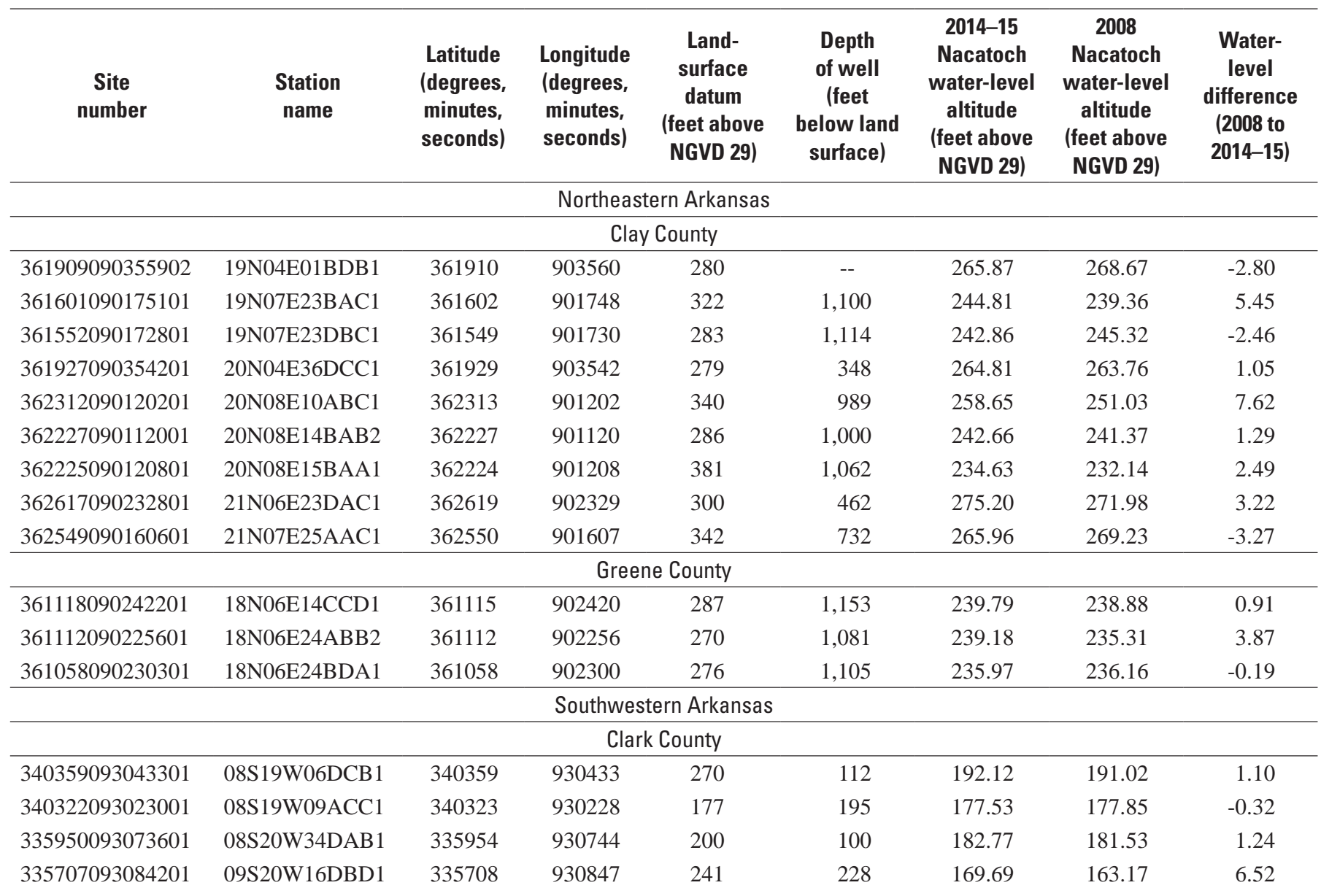




\section{Water-Level Trends and Potentiometric Surfaces in the Nacatoch Aquifer and in the Tokio Aquifer, Arkansas}

Table 2. Difference in depth to water from 2008 to $2014-15$ in the Nacatoch aquifer in northeastern and southwestern Arkansas.Continued

[Horizontal datum is North American Datum of 1983; Vertical datum is referenced to the National Geodetic Vertical Datum of 1929 (NGVD 29); positive values for water-level difference indicate a rise in water levels from 2008 to 2014-15 whereas negative values for water-level difference indicate a decline in water levels from 2008 to $2014-15$; --, no data available]

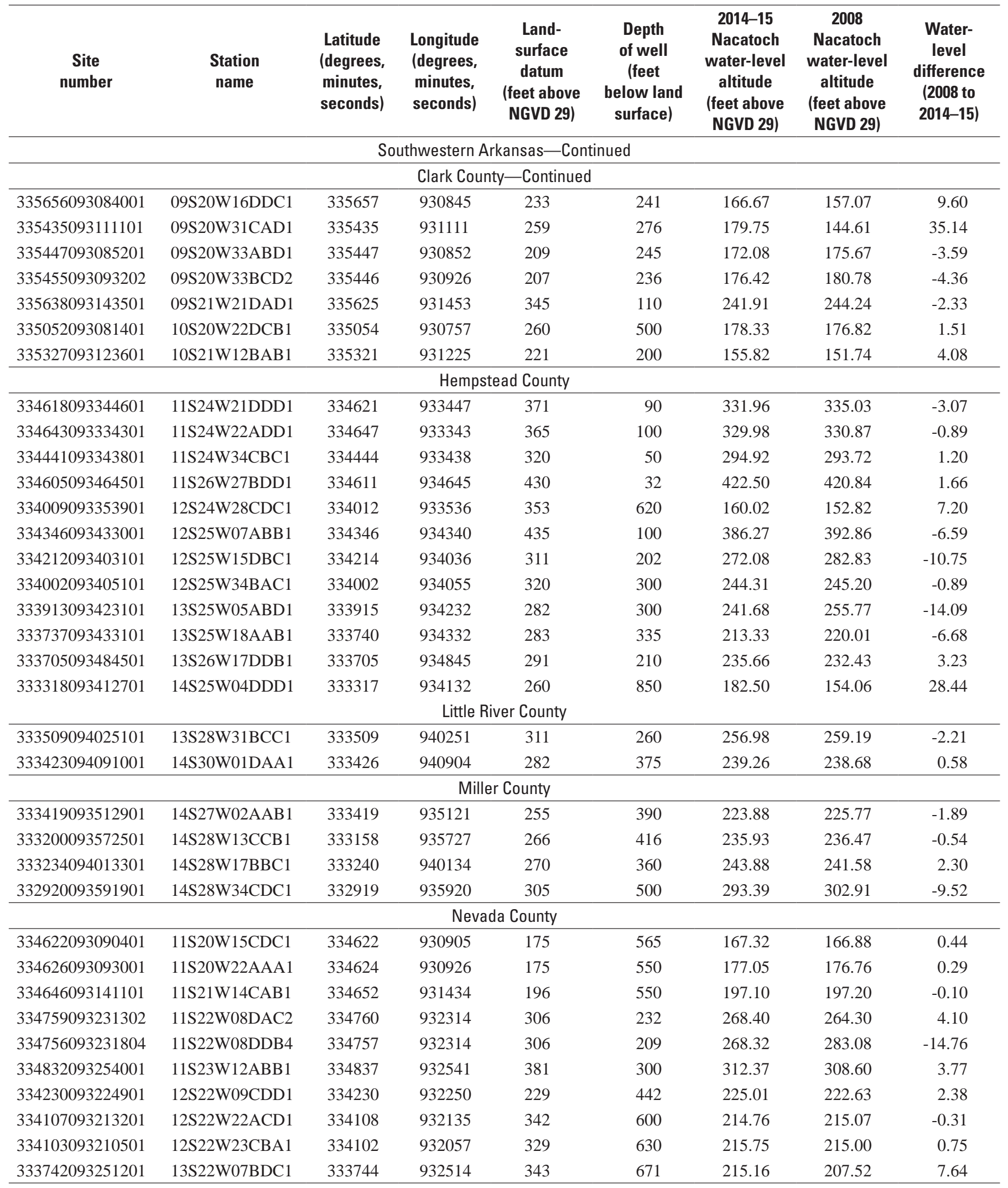




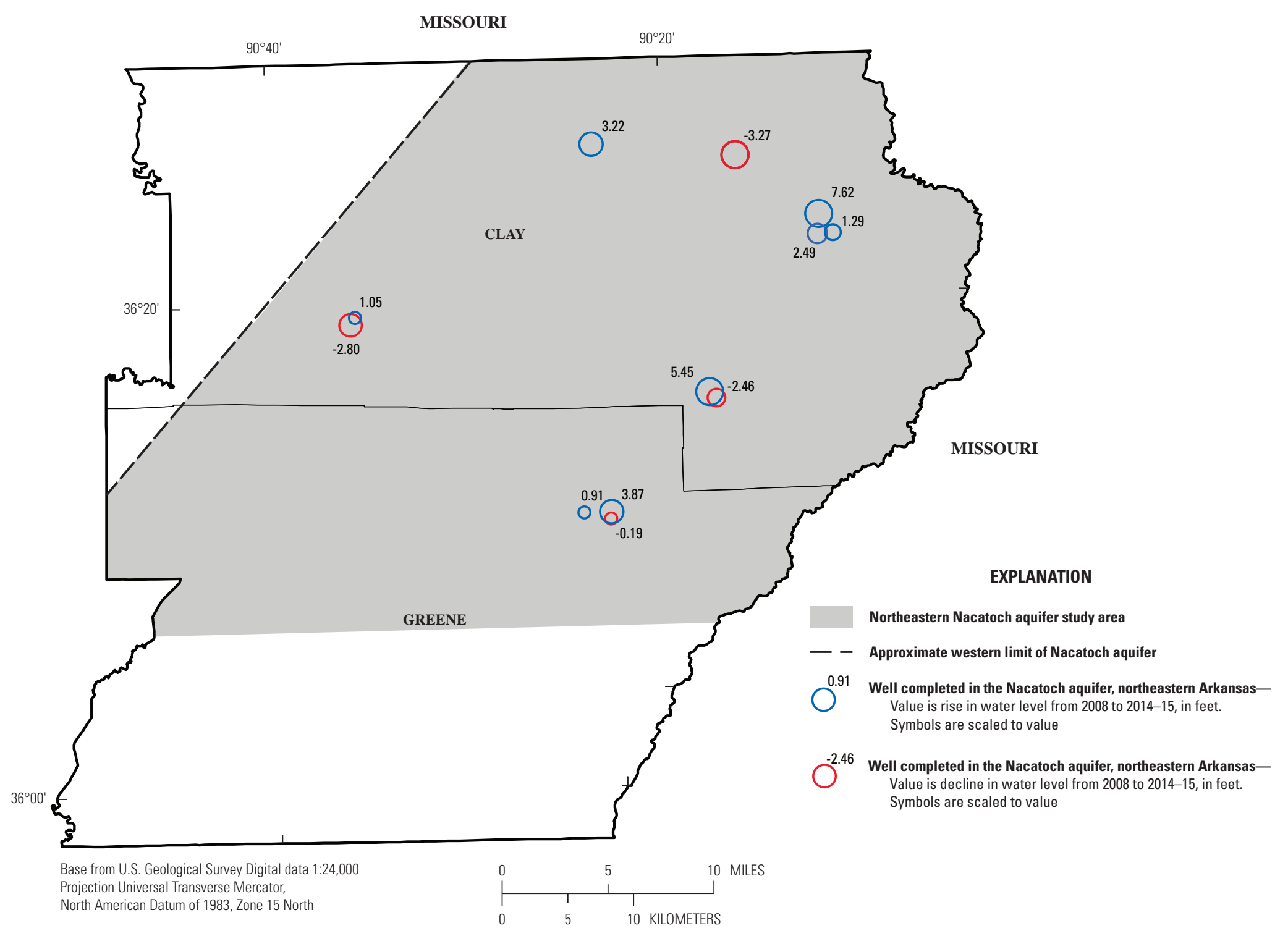

Figure 8. Water-level differences for the Nacatoch aquifer in northeastern Arkansas, 2008 to 2014-15. The circles are scaled in size to represent the relative value of rise or 


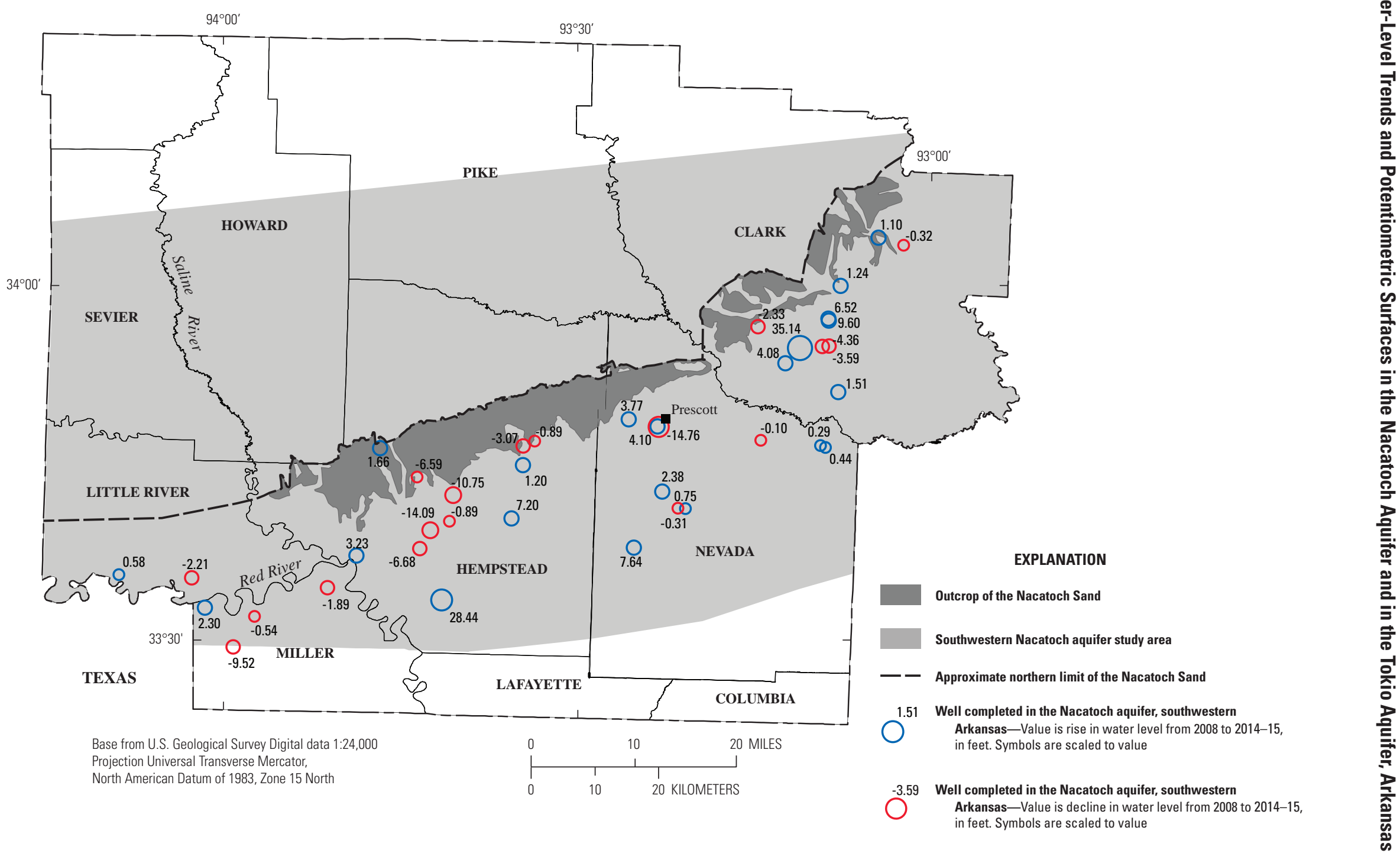

Figure 9. Water-level differences for the Nacatoch aquifer in southwestern Arkansas, 2008 to 2014-15. The circles are scaled in size to represent the relative value of rise or decline. 


\section{Long-Term Water-Level Changes}

Evaluation of long-term data indicates declining water levels in wells screened in the Nacatoch aquifer in both northeastern and southwestern Arkansas. Water-level trends for Clay County well 20N08E10ABC1 (fig. 10A,) indicate a decline of 0.66 foot per year (ft/yr). From 1967 to 2015, water levels declined $33.85 \mathrm{ft}$ likely because water use in Clay County rose by an average of 0.15 million gallons per day per year from 1965 to 2010 (fig. 4) (Halberg and Stephens, 1966; Holland and Ludwig, 1981; Holland, 1987, 1993, 1999, 2004, 2007; Pugh and Holland, 2015). Water-level trends for Greene County well 18N06E14CCD1 (fig. 10B) indicate an annual decline of $0.51 \mathrm{ft} / \mathrm{yr}$ since 1986. From 1978 to 2015, water levels declined $31.23 \mathrm{ft}$. Water use in Greene County in 1965 was unreported; however, in 2010, water use for the county was $0.45 \mathrm{Mgal} / \mathrm{d}$ (fig. 4) (Halberg and Stephens, 1966; Holland and Ludwig, 1981; Holland, 1987, 1993, 1999, 2004, 2007; Pugh and Holland, 2015).

The water-level hydrograph for Clark County well 08S19W09ACC1 (fig. 11A) indicates an annual decline of $0.18 \mathrm{ft} / \mathrm{yr}$ since 1986. Between 1963 and 2014, water levels declined $8.25 \mathrm{ft}$ from $185.91 \mathrm{ft}$ to $177.30 \mathrm{ft}$. Withdrawal rates declined from $0.43 \mathrm{Mgal} / \mathrm{d}$ in 2005 to $0.14 \mathrm{Mgal} / \mathrm{d}$ in 2010 (fig. 5) (Halberg and Stephens, 1966; Holland and Ludwig, 1981; Holland, 1987, 1993, 1999, 2004, 2007; Pugh and Holland, 2015).

The water-level hydrograph for Clark County well 09S20W16DDC1 (fig. 11B) indicates an overall annual decline of $0.33 \mathrm{ft} / \mathrm{yr}$. However, since 1986, water levels have risen approximately $0.44 \mathrm{ft} / \mathrm{yr}$. In 2011, water-level values returned to the 1970 water level when the well was initially measured, which indicates a decline in water use at this well.

The water-level hydrograph for Nevada County well 11S22W08DAC2 (fig. 11C) indicates an annual rise of 2.74 $\mathrm{ft} / \mathrm{yr}$. Between 1985 and 1990, water use declined from 1.11 $\mathrm{Mgal} / \mathrm{d}$ to $0.44 \mathrm{Mgal} / \mathrm{d}$ (Holland, 1987, 1993, 1999, 2004, 2007; Pugh and Holland, 2015) (fig. 5), which coincided with a rise in water levels. Since 1986, water levels in the well have risen $0.33 \mathrm{ft} / \mathrm{yr}$.

The water-level hydrograph for Miller County well 14S28W13CCB1 (fig. 11D) indicates an annual decline of $0.18 \mathrm{ft} / \mathrm{yr}$ since 1986. Withdrawals in Miller County have remained relatively stable since 2005 (Holland, 2007; Schrader and Rodgers, 2013). 


\section{A. CLAY COUNTY 20N08E10ABC1}

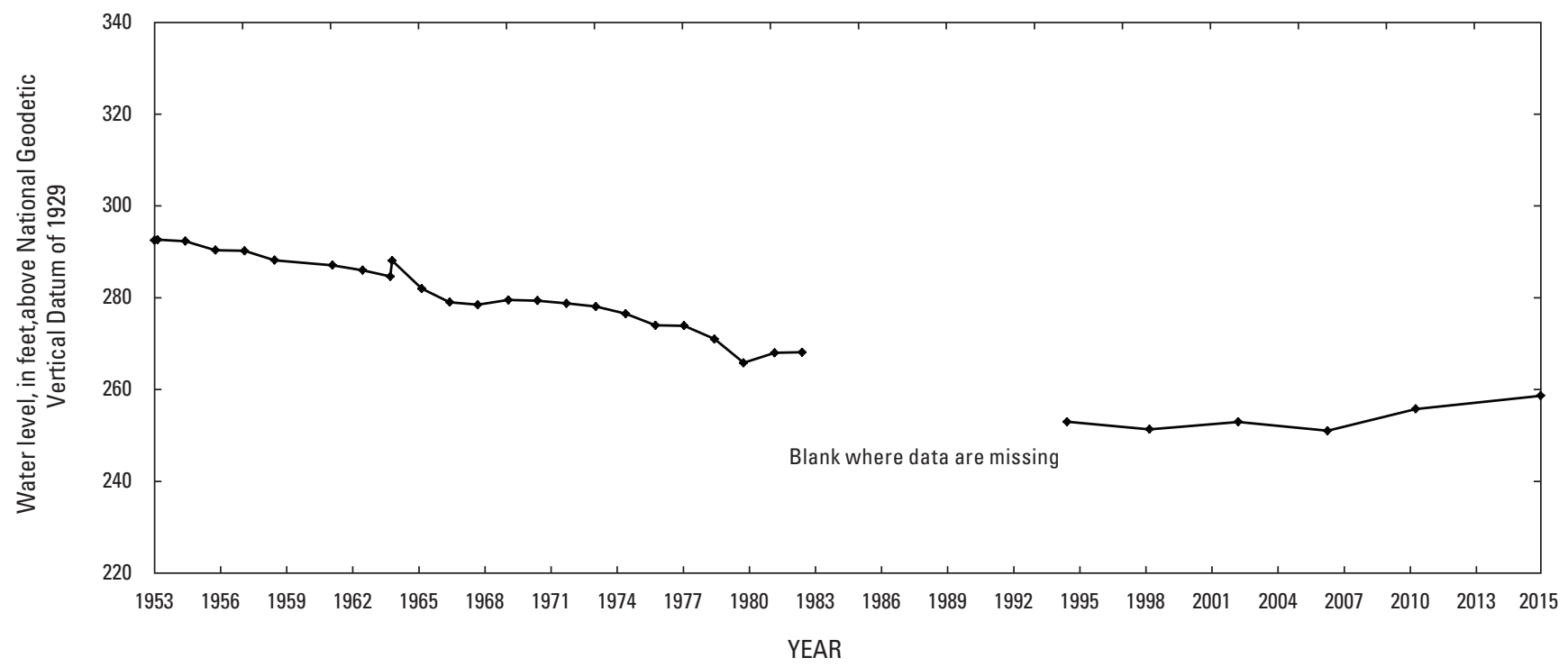

\section{B. GREENE COUNTY 18N06E14CCD1}

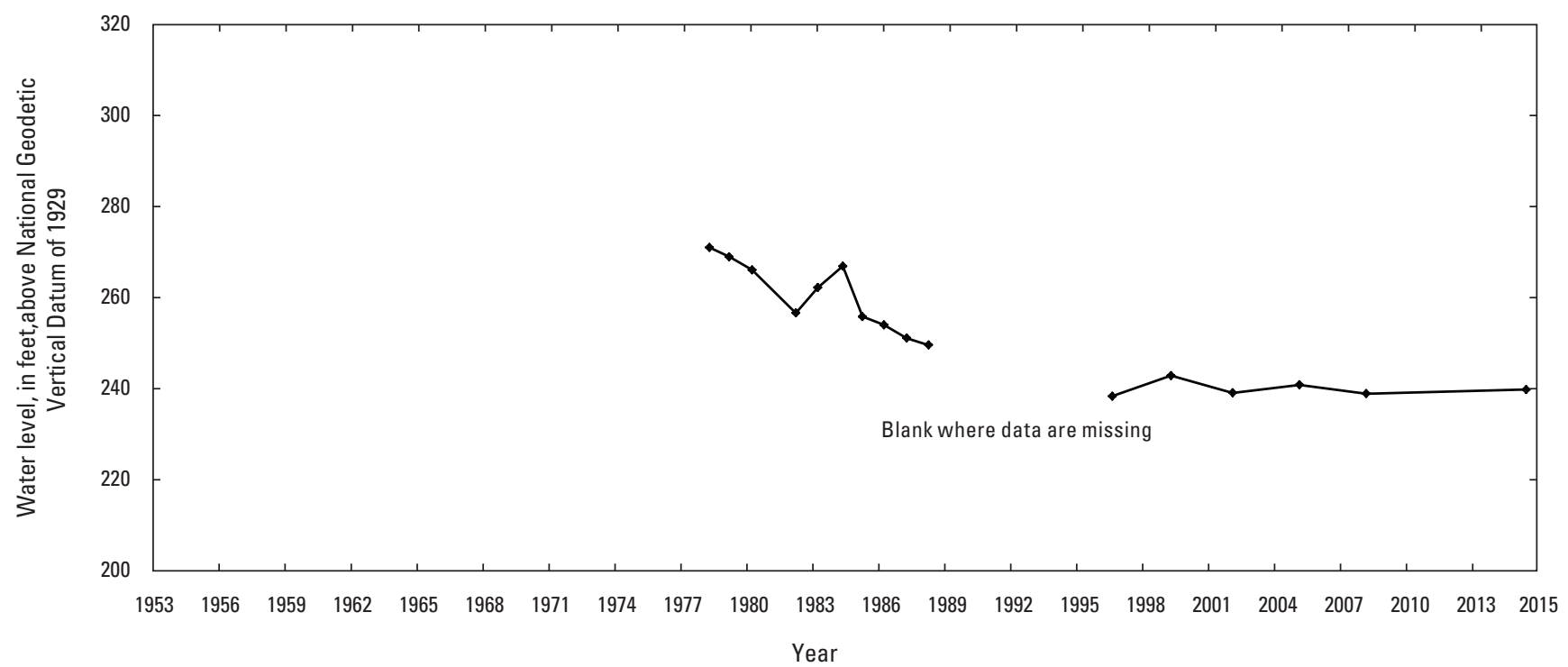

Figure 10. Water-level hydrographs for selected wells completed in the Nacatoch aquifer in northeastern Arkansas. 


\section{A. CLARK COUNTY 08S19W09ACC1}

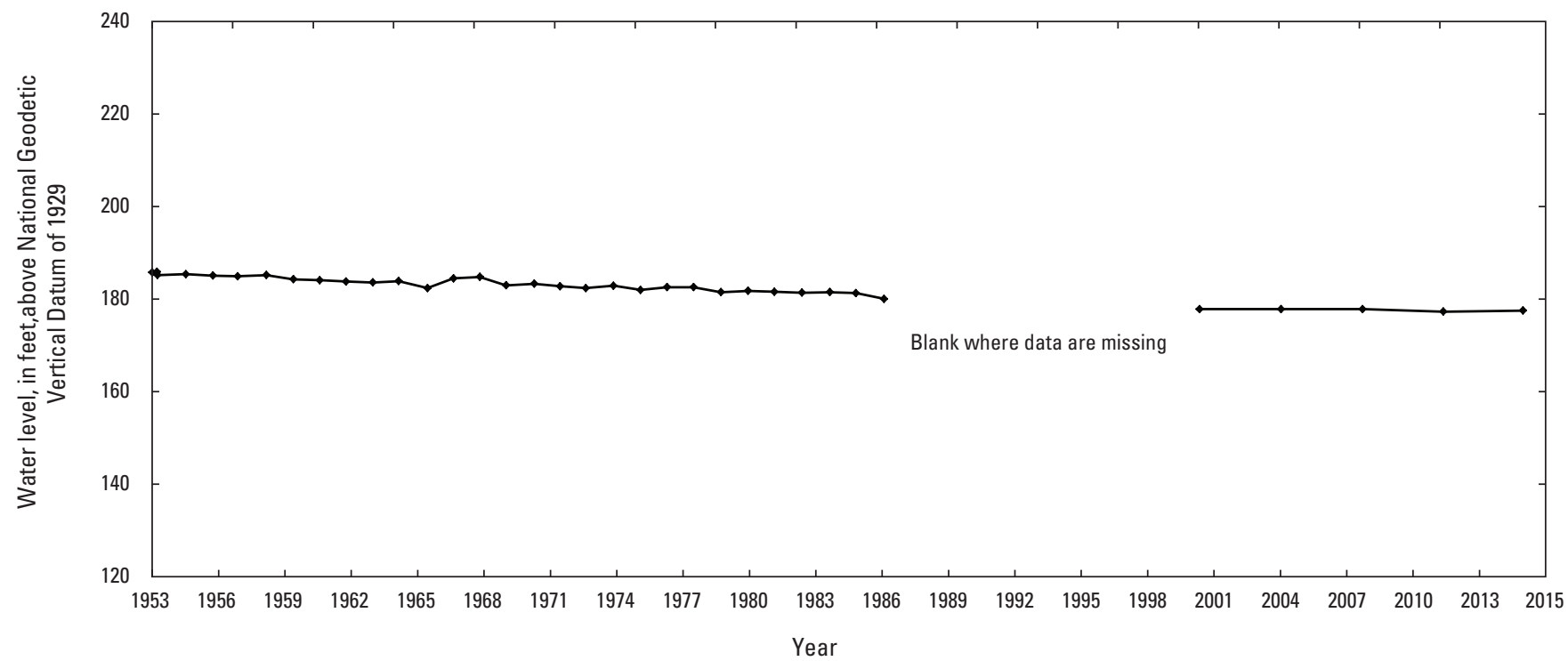

\section{B. CLARK COUNTY 09S20W16DDC1}

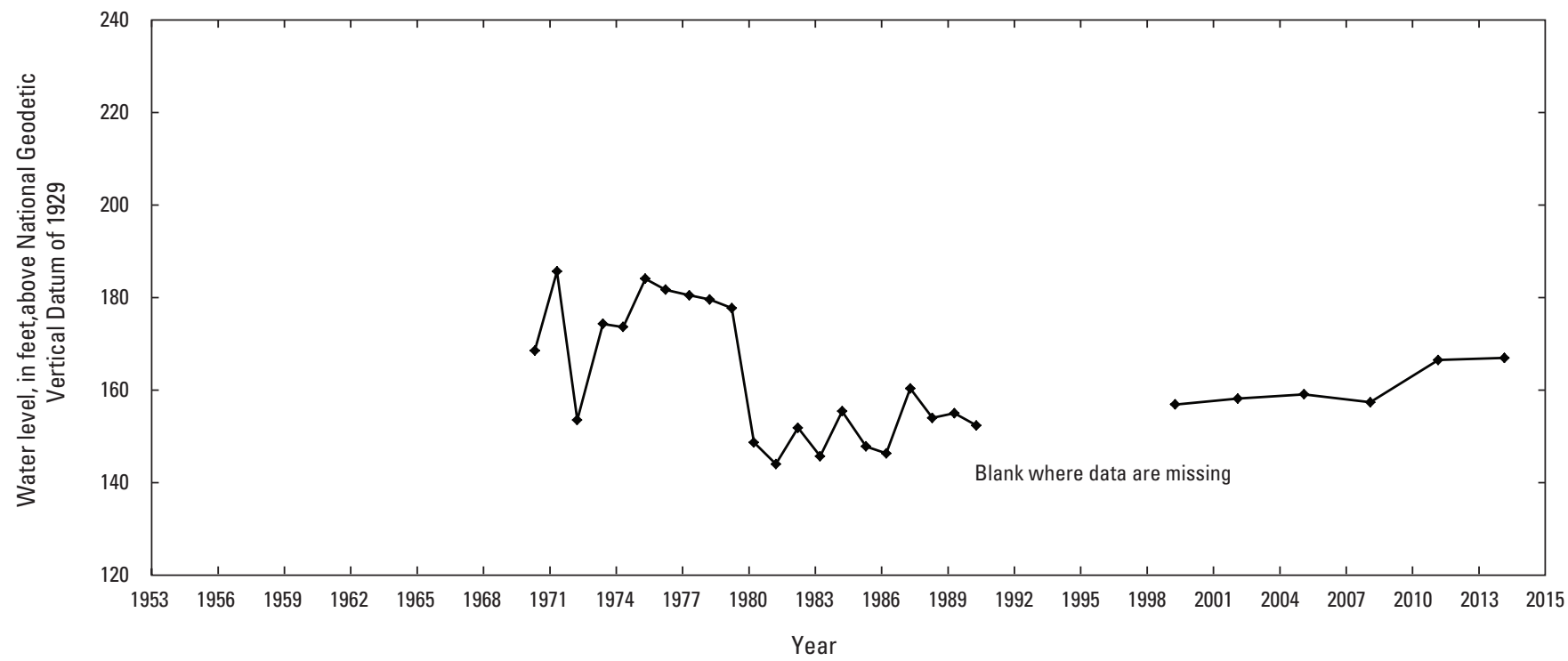

Figure 11. Water-level hydrographs for selected wells completed in the Nacatoch aquifer in southwestern Arkansas. 


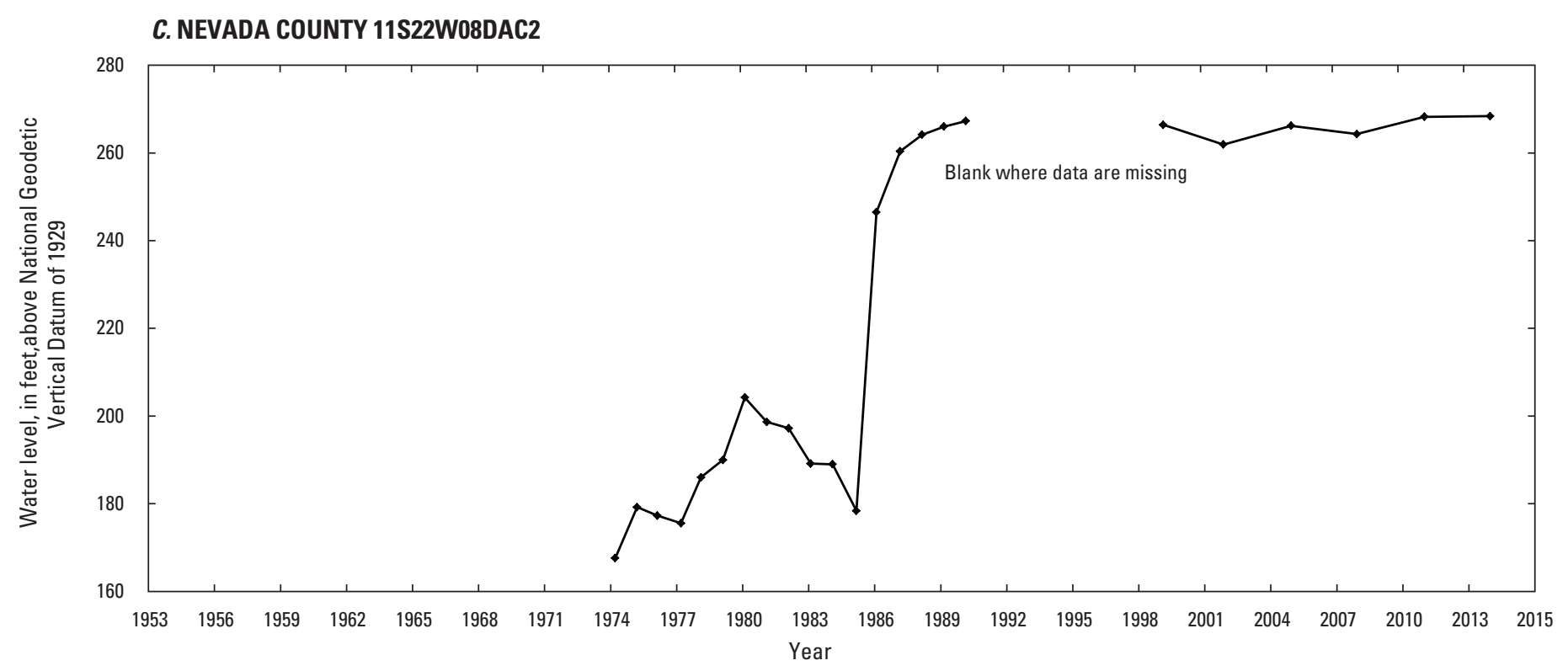

D. MILLER COUNTY 14S28W13CCB1

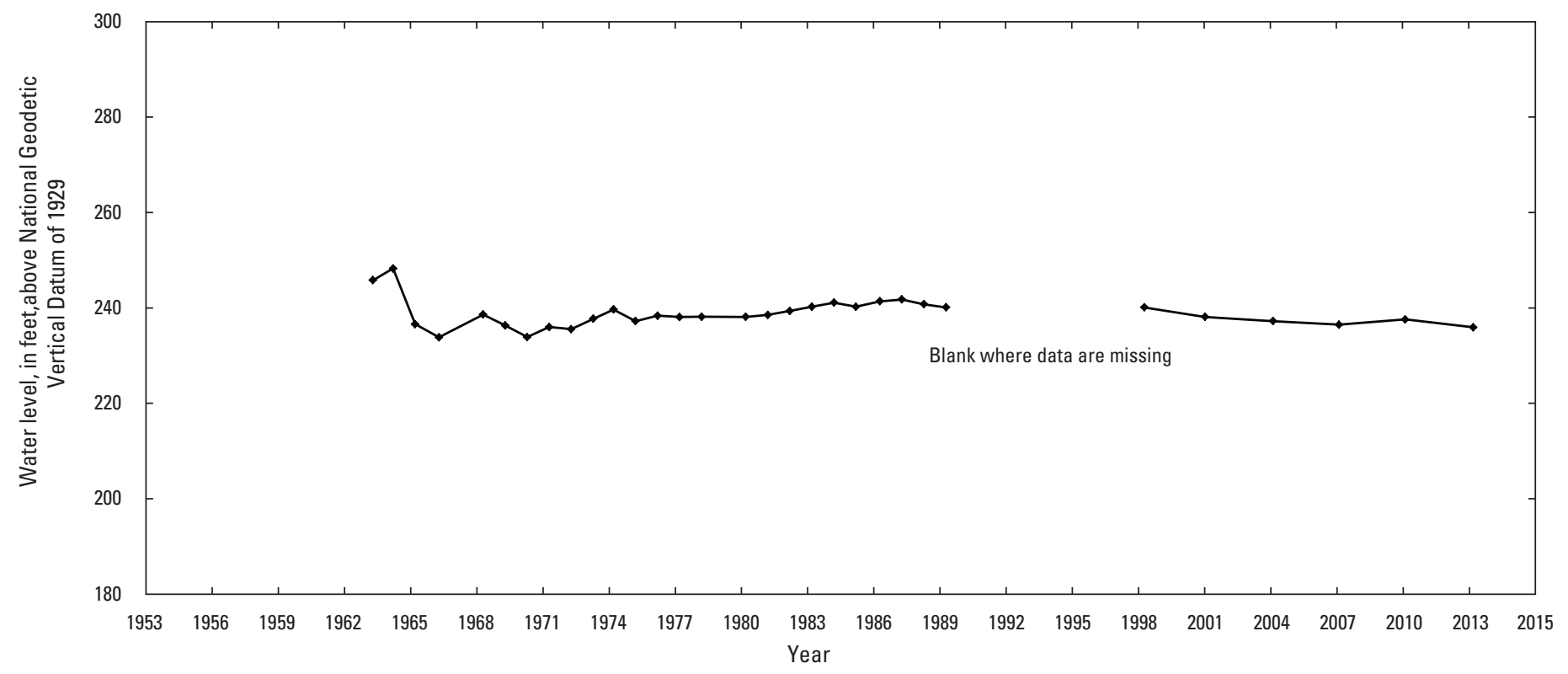

Figure 11. Water-level hydrographs for selected wells completed in the Nacatoch aquifer in southwestern Arkansas.-Continued 


\section{Tokio Aquifer}

\section{Hydrogeologic Setting}

The Tokio aquifer is stratigraphically below the Nacatoch aquifer and is separated by five stratigraphic units, listed here in descending order: Saratoga Chalk, Marlbrook Marl, Annona Chalk, Ozan Formation, and Brownstown Marl (fig. 2). These five units can reach a thickness of as much as $900 \mathrm{ft}$ and are rarely used as water sources (Cushing and others, 1964). The Tokio aquifer is formed by the Tokio Formation in Clark, Pike, Hempstead, Howard, Sevier, and Little River Counties (Miser and Perdue, 1918) and by the Woodbine Formation in Little River, Sevier, Howard, and northwestern Hempstead Counties (Boswell and others, 1965) that are all of Cretaceous age (fig. 3). Rocks forming the Tokio aquifer unconformably overlie consolidated rocks of Mississippian and Pennsylvanian age in Clark and northeastern Nevada Counties (Plebuch and Hines, 1969) and the Trinity Group of Early Cretaceous age in Pike, Nevada, Miller, and most of Hempstead Counties (Petersen and others, 1985). The aquifer is not present in the northeastern part of Arkansas (Kresse and others, 2015) and crops out in a southwest-to-northeast trending band from eastern Sevier County to west-central Clark County. The outcrop attains a maximum width of about $10 \mathrm{mi}$ in Howard County and extends approximately $8 \mathrm{mi}$ to the southwest into Sevier County. In this area, the aquifer is overlain in several places by terrace deposits of Quaternary alluvium. The unit ranges in thickness from about $50 \mathrm{ft}$ to more than $300 \mathrm{ft}$, dips toward the southeast, and is composed of discontinuous, interbedded gray clay and poorly sorted, cross-bedded quartz sands, lignite, and basal gravel (Counts and others, 1955; Boswell and others, 1965; Plebuch and Hines, 1969; Petersen and others, 1985).

The Tokio aquifer yields potable water to wells in eastern Little River County, southeastern Sevier County, southern Howard and Pike Counties, western Clark County, northern and central Hempstead County, and northwestern Nevada County. Wells penetrating the aquifer range in depth from a few feet in the outcrop area to about 1,200 ft at Hope and Prescott (Ludwig, 1972). Wells in central Hempstead County yield as much as $300 \mathrm{gal} / \mathrm{min}$. Artesian wells, which produce as much as $90 \mathrm{gal} / \mathrm{min}$, are in the bottom-land areas adjacent to streams (Counts and others, 1955). Historical records indicate that water levels in wells screened in the aquifer did not decline appreciably from 1959 to 1968, and that water levels were not greatly affected by withdrawal of water at Hope and Prescott during this period (Ludwig, 1972).

Estimates of water withdrawn from the Tokio aquifer rose by 201 percent from $2.00 \mathrm{Mgal} / \mathrm{d}$ in 1965 to $6.02 \mathrm{Mgal} / \mathrm{d}$ in 1980 (fig. 12) but had declined to $1.8 \mathrm{Mgal} / \mathrm{d}$ in 2000 . In 2005, water withdrawn from the aquifer was estimated to be $4.4 \mathrm{Mgal} / \mathrm{d}$, an increase of 144 percent from 2000. Water withdrawn from the aquifer was estimated to be $3.13 \mathrm{Mgal} / \mathrm{d}$ in 2010, a decline of 29 percent from 2005 (Halberg and Stephens, 1966; Holland and Ludwig, 1981; Holland, 1999, 2004, 2007; Pugh and Holland, 2015). Between 1985 and 2000, water use in Clark County increased from $0.04 \mathrm{Mgal} / \mathrm{d}$ to $0.7 \mathrm{Mgal} /$ day. From 1985 to 1995, water use decreased

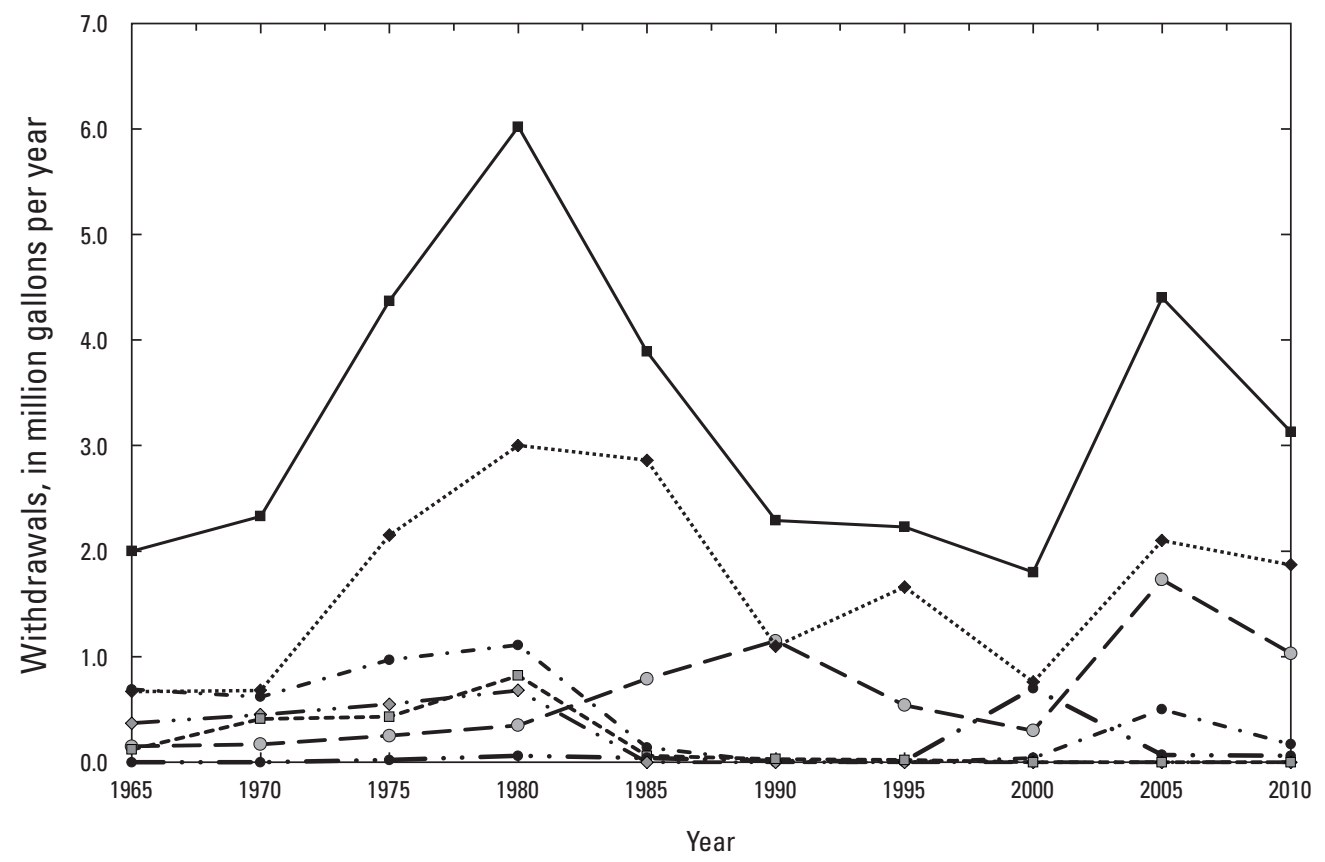

Figure 12. Estimated withdrawals by county from the Tokio aquifer for the southwestern study area.

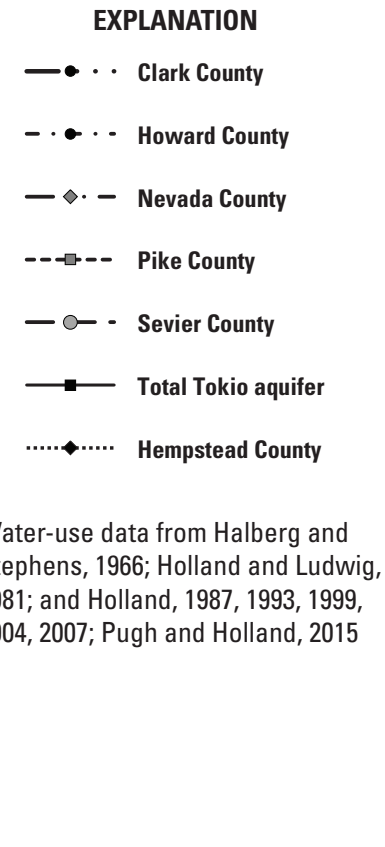




\section{Water-Level Trends and Potentiometric Surfaces in the Nacatoch Aquifer and in the Tokio Aquifer, Arkansas}

from 0.06 Mgal/d to 0.02 Mgal/d in Pike County. Water use for Pike County was not reported in 2000. In Howard County, water use was reported in 1985 (0.14 Mgal/d) and in 2000 (0.04 Mgal/d) but was not reported in 1990 and 1995. Water use was not reported for Nevada County between 1985 and 2000.

Recharge to the aquifer is from precipitation where it crops out or is overlain by permeable alluvial and terrace deposits. At the outcrop, the soil is weathered to a sandy consistency that facilitates the percolation of rain and surface water into the sand (Counts and others, 1955). The aquifer yields freshwater to within a few miles north of Ashdown in Little River County then increases in salinity downdip (southeast) from near Prescott to the fault zone trending across Nevada County (Petersen and others, 1985).

\section{Potentiometric Surface}

The potentiometric surface indicates that groundwater flow in the Tokio aquifer, in general, is perpendicular to contour lines in the direction of the downward hydraulic gradient, toward the city of Hope. In east-central Howard County, groundwater flows from a water-level altitude of $491 \mathrm{ft}$ above NGVD 29 in the outcrop area to a water-level altitude of $105 \mathrm{ft}$ above NGVD 29 approximately $5 \mathrm{mi}$ northwest of the city of Hope (table 3), in Hempstead County. In southwestern Pike, northwestern Nevada, and southeastern Hempstead Counties, an area of artesian flow exists as evidenced by five flowing artesian wells. Northwest of the city of Hope, an apparent cone of depression exists, which may be a result of groundwater withdrawal in the area (fig. 13). Waterlevel data were not available for the area south of Hope.

\section{Water-Level Trends}

\section{Water-Level Differences from 2008 to 2014}

Water-level differences between measurements from 2008 and 2014 in 37 wells show a decline in more than half of the measured wells (fig. 14; table 4). The largest waterlevel rise was $21.34 \mathrm{ft}$ in Hempstead County, and the largest water-level decline was $39.37 \mathrm{ft}$ in Clark County (table 4). In general, there were declines in Hempstead and Nevada Counties and water-level rises in Sevier County.

In Clark County, no overall trend existed between 2008 and 2014. Of the four water-level difference values calculated, two water levels rose and two water levels declined. The greatest rise (9.64 ft) was measured in well 09S22W05BBB1 located near the Saline River. The greatest decline (39.37 ft) occurred near the outcrop area in well 08S22W15ABB2. Analysis of water-use trends in the area of water-level decline does not provide a reason for the decline. Water levels declined in both wells measured in Nevada County. Water levels declined by $2.43 \mathrm{ft}$ in well 11S22W08DAC8 and $1.57 \mathrm{ft}$ in well 12S21W28ADA1.

Of the 16 wells measured in Hempstead County, water levels declined in 11 wells and rose in 5 wells. Water-level changes ranged from a decline of $27.83 \mathrm{ft}$ in well 12S24W06DAD1 to a rise of $21.34 \mathrm{ft}$ in well 12S27W05AAC1 in west-central Hempstead County. Water levels in three wells in or near the outcrop area indicated a rise in water levels.

Water levels rose in 5 of the 9 wells measured in Howard County. The rise in water levels ranged from $18.78 \mathrm{ft}$ in well 10S27W02ACD1 in southeastern Howard County to 2.14 $\mathrm{ft}$ in well 09S27W03DBD1 in the outcrop area of the Tokio aquifer in east-central Howard County. Water-level declines in southern Howard County are in or near the outcrop area with values ranging from $4.86 \mathrm{ft}$ in well 09S27W10BCB1 to $0.10 \mathrm{ft}$ in well 09S27W18ADB1. Water-level rises in three wells in southern Sevier County ranged from $1.06 \mathrm{ft}$ in well 11S29W13CCD1 to $5.40 \mathrm{ft}$ near the Saline River in well 10S28W31DCC1.

\section{Long-Term Water-Level Changes}

The water-level hydrograph for Hempstead County well 09S23W33CDA1 (fig. 15A) indicates an annual decline of $0.03 \mathrm{ft} / \mathrm{yr}$ from 1986 to 2014 . The water-level hydrograph of Hempstead County well 09S26W18CBB1 (fig. 15B) indicates an annual decline of $0.22 \mathrm{ft} / \mathrm{yr}$ since 1986. The water-level hydrograph for Hempstead County well 12S24W06DAD1 (fig. 15C) indicates an annual waterlevel decline of $2.56 \mathrm{ft} / \mathrm{yr}$ over the 43-year period of record. Since 1986, the water level has declined $3.10 \mathrm{ft} / \mathrm{yr}$. The decline in water level may be associated with increased withdrawals from the Tokio aquifer in Hempstead County (Schrader and Rodgers, 2013) as evidenced by an apparent cone of depression near Hope where a large decline in water level between 2008 and 2014 (27.83 ft.) is observed. Factors such as climatic change or leakage to and from overlying and underlying rock units may have also contributed to the fluctuation in the measured water levels. 
Table 3. Water-level data collected in 2014 from wells completed in the Tokio aquifer in southwestern Arkansas.

[Horizontal datum is North America Datum of 1983; Vertical datum is referenced to the National Geodetic Vertical Datum of 1929 (NGVD 29); Letters in parentheses correspond to well locations in figure 13 and well hydrographs in figure 15. Values rounded to the nearest whole number]

\begin{tabular}{|c|c|c|c|c|c|c|c|}
\hline $\begin{array}{c}\text { Site } \\
\text { number }\end{array}$ & $\begin{array}{l}\text { Station } \\
\text { name }\end{array}$ & $\begin{array}{l}\text { Latitude } \\
\text { (degrees, } \\
\text { minutes, } \\
\text { seconds) }\end{array}$ & $\begin{array}{l}\text { Longitude } \\
\text { (degrees, } \\
\text { minutes, } \\
\text { seconds) }\end{array}$ & $\begin{array}{c}\text { Water-level } \\
\text { altitude } \\
\text { (feet above } \\
\text { NGVD 29) }\end{array}$ & $\begin{array}{c}\text { Depth to } \\
\text { water } \\
\text { (feet below } \\
\text { land surface) }\end{array}$ & $\begin{array}{c}\text { Land-surface } \\
\text { datum } \\
\text { (feet above } \\
\text { NGVD 29) }\end{array}$ & $\begin{array}{c}\text { Date of } \\
\text { measurement }\end{array}$ \\
\hline 340311093203701 & 08S22W15ABB2 & 340313 & 932018 & 232 & 93 & 325 & $3 / 26 / 2014$ \\
\hline 335951093225901 & 09S22W05BBB1 & 335951 & 932259 & 214 & 98 & 312 & 3/24/2014 \\
\hline 335754093212001 & 09S22W16ACA1 & 335754 & 932120 & 220 & 13 & 233 & $3 / 24 / 2014$ \\
\hline \multicolumn{8}{|c|}{ Hempstead County } \\
\hline 335710093285801 & 09S23W20BDA1 & 335710 & 932859 & 250 & 0 & 250 & $3 / 11 / 2014$ \\
\hline 335453093275601 & 09S23W33CDA1 (A) & 335457 & 932802 & 271 & -1 & 270 & 3/11/2014 \\
\hline 335634093313201 & 09S24W25BBB1 & 335633 & 933132 & 268 & 0 & 268 & 3/11/2014 \\
\hline 335844093465401 & 09S26W09CDC1 & 335846 & 934656 & 422 & 3 & 425 & 3/13/2014 \\
\hline 335819093492501 & 09S26W18CBB1 (B) & 335815 & 934921 & 400 & 25 & 425 & 3/13/2014 \\
\hline 335048093431001 & 10S25W30CCD1 & 335048 & 934310 & 299 & 89 & 388 & 3/13/2014 \\
\hline 335508093461301 & 10S26W03BBA1 & 335507 & 934612 & 366 & 1 & 367 & 3/13/2014 \\
\hline 334903093490901 & 11S26W08BBB1 & 334909 & 934903 & 300 & 72 & 372 & 3/13/2014 \\
\hline 334716093455801 & 11S26W23BBB1 & 334720 & 934602 & 249 & 170 & 419 & 3/13/2014 \\
\hline 334358093370101 & 12S24W06DAD1 (C) & 334360 & 933701 & 105 & 250 & 355 & 3/11/2014 \\
\hline 334341093390201 & 12S25W02DDD1 & 334341 & 933902 & 120 & 247 & 367 & 3/20/2014 \\
\hline 334447093335801 & 12S27W04BBC1 & 334450 & 935358 & 261 & 174 & 435 & 3/18/2014 \\
\hline 334439093541601 & 12S27W05AAC1 & 334449 & 935421 & 280 & 155 & 435 & 3/18/2014 \\
\hline 335454093505501 & 10S27W02ACD1 & 335454 & 935056 & 301 & 57 & 358 & 3/17/2014 \\
\hline 335512093532901 & 10S27W04BBD1 & 335512 & 935330 & 345 & 47 & 392 & 3/17/2014 \\
\hline 335356093502001 & 10S27W12CAB1 & 335356 & 935021 & 304 & 79 & 383 & 3/18/2014 \\
\hline 335336093553401 & 10S27W18BAC1 & 335336 & 935535 & 323 & 99 & 422 & 3/17/2014 \\
\hline 334603093541801 & 11S27W21CDA1 & 334603 & 935418 & 214 & 66 & 280 & 3/18/2014 \\
\hline \multicolumn{8}{|c|}{ Nevada County } \\
\hline 334757093231208 & 11S22W08DAC8 & 334757 & 932312 & 211 & 94 & 305 & $3 / 20 / 2014$ \\
\hline 334015093155901 & 12S21W28ADA1 & 334015 & 931559 & 262 & 3 & 265 & 3/20/2014 \\
\hline \multicolumn{8}{|c|}{ Pike County } \\
\hline 340213093293001 & 08S23W19ADC1 & 340213 & 932931 & 351 & -1 & 350 & $2 / 20 / 2014$ \\
\hline 340018092255001 & 08S23W35DCA1 & 340004 & 932530 & 259 & -2 & 257 & $2 / 21 / 2014$ \\
\hline 335750093314201 & 09S24W14AAD1 & 335810 & 933139 & 286 & -1 & 285 & $2 / 20 / 2014$ \\
\hline \multicolumn{8}{|c|}{ Sevier County } \\
\hline 335040094015401 & 10S28W31DCC1 & 335026 & 940145 & 294 & 36 & 330 & $3 / 18 / 2014$ \\
\hline 334949094065201 & 11S29W05DCA1 & 334949 & 940653 & 324 & 156 & 480 & 3/18/2014 \\
\hline 334907094070301 & 11S29W08DBB1 & 334907 & 940704 & 324 & 141 & 465 & 3/18/2014 \\
\hline 334750094031301 & 11S29W13CCD1 & 334750 & 940317 & 280 & 80 & 360 & 3/18/2014 \\
\hline
\end{tabular}




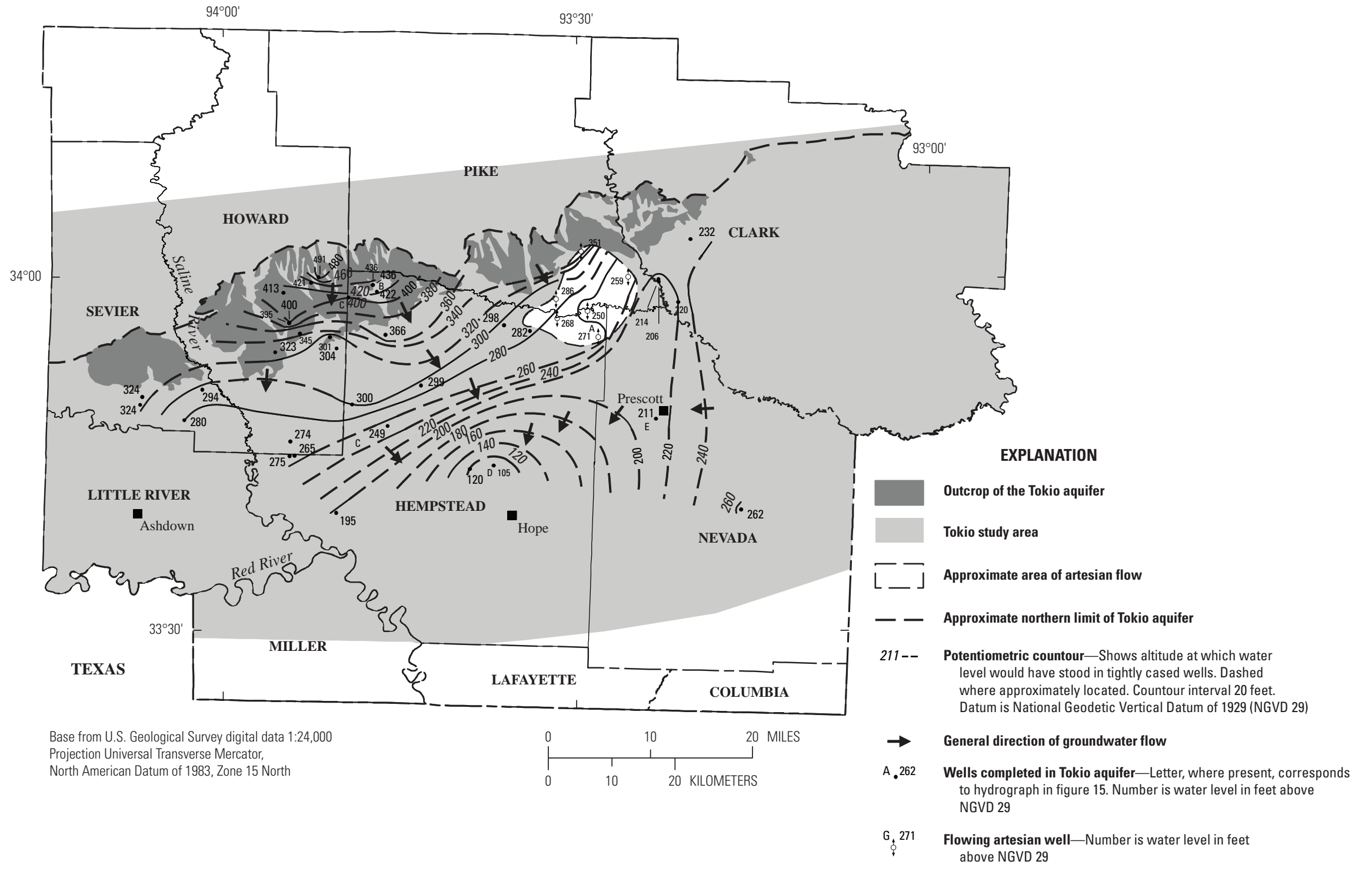

Figure 13. Potentiometric surface of the Tokio aquifer in southwestern Arkansas, 2014. 


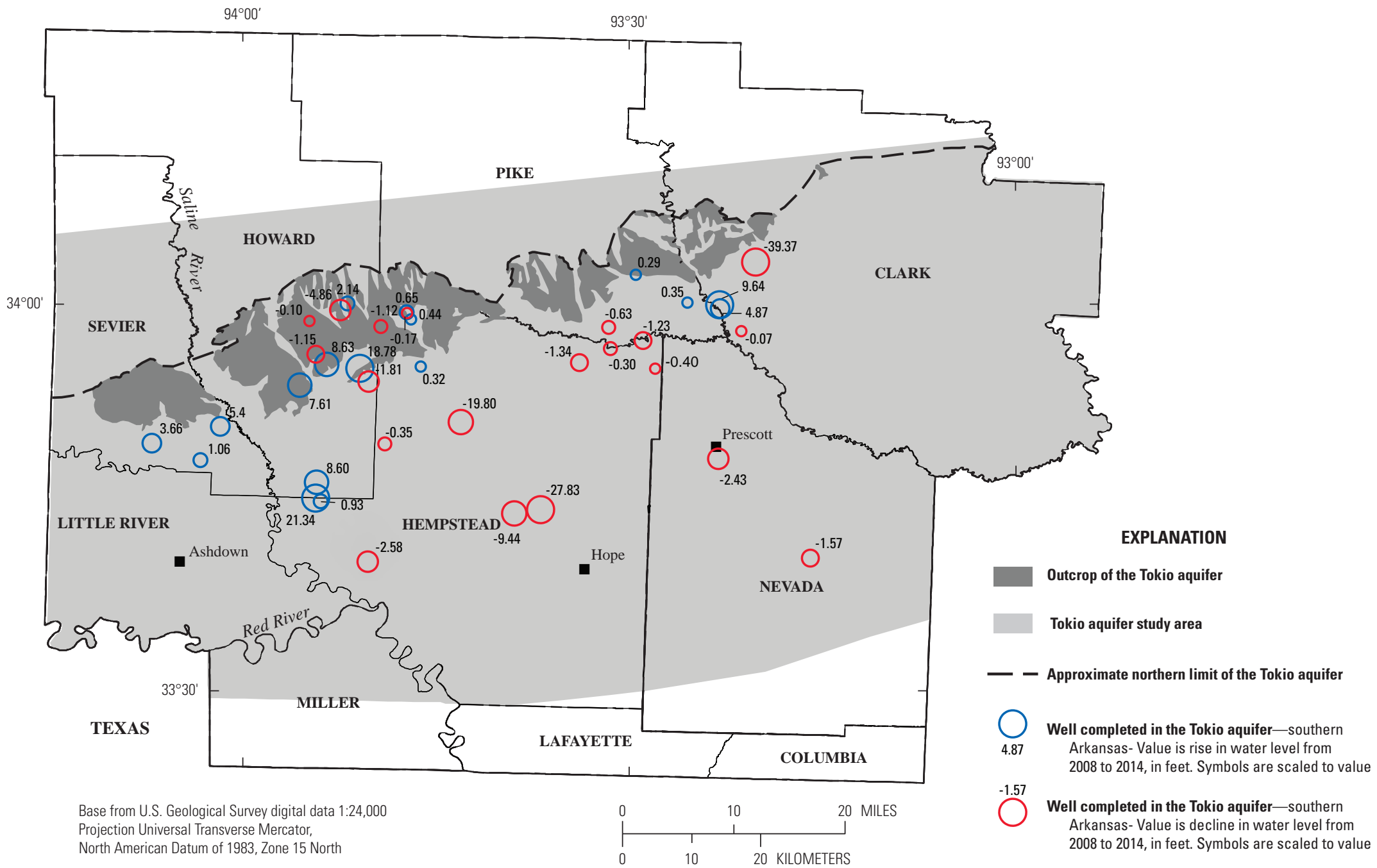

Figure 14. Water-level differences for the Tokio aquifer in southwestern Arkansas, 2008-14. The circles are scaled in size to represent the relative value of rise or decline. 


\section{Water-Level Trends and Potentiometric Surfaces in the Nacatoch Aquifer and in the Tokio Aquifer, Arkansas}

Table 4. Difference in depth to water from 2008 to 2014 in the Tokio aquifer in southwestern Arkansas.

[Horizontal datum is North American Datum of 1983; Vertical datum is referenced to the National Geodetic Vertical Datum of 1929 (NGVD 29); positive values for water-level difference indicate a rise in water levels from 2008 to 2014 whereas negative values for water-level difference indicate a decline in water levels from 2008 to 2014 ; --, no data available]

\begin{tabular}{|c|c|c|c|c|c|c|c|c|}
\hline $\begin{array}{c}\text { Site } \\
\text { number }\end{array}$ & $\begin{array}{c}\text { Station } \\
\text { name }\end{array}$ & $\begin{array}{c}\text { Latitude } \\
\text { (degrees, } \\
\text { minutes, } \\
\text { seconds) }\end{array}$ & $\begin{array}{c}\text { Longitude } \\
\text { (degrees, } \\
\text { minutes, } \\
\text { seconds) }\end{array}$ & $\begin{array}{c}\text { Land- } \\
\text { surface } \\
\text { datum } \\
\text { (feet above } \\
\text { NGVD 29) }\end{array}$ & $\begin{array}{c}\text { Depth of } \\
\text { well } \\
\text { (feet } \\
\text { below land } \\
\text { surface) }\end{array}$ & $\begin{array}{c}2014 \text { Tokio } \\
\text { water-level } \\
\text { altitude } \\
\text { (feet above } \\
\text { NGVD 29) }\end{array}$ & $\begin{array}{c}2008 \text { Tokio } \\
\text { water-level } \\
\text { altitude } \\
\text { (feet above } \\
\text { NGVD 29) }\end{array}$ & $\begin{array}{c}\text { Water- } \\
\text { level } \\
\text { difference } \\
\text { (2008-14) }\end{array}$ \\
\hline \multicolumn{9}{|c|}{ Clark County } \\
\hline 340311093203701 & 08S22W15ABB2 & 340313 & 932018 & 325 & 145 & 232.04 & 271.41 & -39.37 \\
\hline 335754093212001 & 09S22W16ACA1 & 335754 & 932120 & 233 & 450 & 219.70 & 219.77 & -0.07 \\
\hline \multicolumn{9}{|c|}{ Hempstead County } \\
\hline 335710093285801 & 09S23W20BDA1 & 335710 & 932859 & 250 & 210 & 250.00 & 251.23 & -1.23 \\
\hline 335453093275601 & 09S23W33CDA1 & 335457 & 932802 & 270 & 467 & 270.91 & 270.95 & -0.04 \\
\hline 335634093313201 & 09S24W25BBB1 & 335633 & 933132 & 268 & 270 & 268.20 & 268.50 & -0.30 \\
\hline 335844093465401 & 09S26W09CDC1 & 335846 & 934656 & 425 & 16 & 421.55 & 421.11 & 0.44 \\
\hline 335819093492501 & 09S26W18CBB1 & 335815 & 934921 & 425 & 29.5 & 400.34 & 401.46 & -1.12 \\
\hline 335048093431001 & 10S25W30CCD1 & 335048 & 934310 & 388 & 500 & 298.88 & 318.68 & -19.80 \\
\hline 335508093461301 & 10S26W03BBA1 & 335507 & 934612 & 367 & 162 & 366.14 & 365.82 & 0.32 \\
\hline 334903093490901 & 11S26W08BBB1 & 334909 & 934903 & 372 & 550 & 300.07 & 300.42 & -0.35 \\
\hline 334358093370101 & 12S24W06DAD1 & 334360 & 933701 & 355 & 1,140 & 104.61 & 132.44 & -27.83 \\
\hline 334341093390201 & 12S25W02DDD1 & 334341 & 933902 & 367 & 1,159 & 119.64 & 129.08 & -9.44 \\
\hline 334447093335801 & 12S27W04BBC1 & 334450 & 935358 & 435 & 870 & 261.10 & 260.17 & 0.93 \\
\hline 334439093541601 & 12S27W05AAC1 & 334449 & 935421 & 435 & 906 & 280.12 & 258.78 & 21.34 \\
\hline 335512093532901 & 10S27W04BBD1 & 335512 & 935330 & 392 & 170 & 345.15 & 336.52 & 8.63 \\
\hline 335356093502001 & 10S27W12CAB1 & 335356 & 935021 & 383 & 416 & 304.21 & 306.02 & -1.81 \\
\hline 335336093553401 & 10S27W18BAC1 & 335336 & 935535 & 422 & 300 & 322.74 & 315.13 & 7.61 \\
\hline 334603093541801 & 11S27W21CDA1 & 334603 & 935418 & 280 & 800 & 213.58 & 204.98 & 8.60 \\
\hline \multicolumn{9}{|c|}{ Nevada County } \\
\hline 334757093231208 & 11S22W08DAC8 & 334757 & 932312 & 305 & 1,050 & 211.10 & 213.53 & -2.43 \\
\hline 334015093155901 & 12S21W28ADA1 & 334015 & 931559 & 265 & -- & 261.51 & 263.08 & -1.57 \\
\hline \multicolumn{9}{|c|}{ Pike County } \\
\hline 340213093293001 & 08S23W19ADC1 & 340213 & 932931 & 350 & 105 & 351.30 & 351.01 & 0.29 \\
\hline 340018092255001 & 08S23W35DCA1 & 340004 & 932530 & 257 & 125 & 258.50 & 258.15 & 0.35 \\
\hline 335750093314201 & 09S24W14AAD1 & 335810 & 933139 & 285 & 140 & 286.00 & 286.63 & -0.63 \\
\hline \multicolumn{9}{|c|}{ Sevier County } \\
\hline 335040094015401 & 10S28W31DCC1 & 335026 & 940145 & 330 & 185 & 293.56 & 288.16 & 5.40 \\
\hline 334907094070301 & 11S29W08DBB1 & 334907 & 940704 & 465 & 395 & 323.83 & 320.17 & 3.66 \\
\hline 334750094031301 & 11S29W13CCD1 & 334750 & 940317 & 360 & 339 & 279.64 & 278.58 & 1.06 \\
\hline
\end{tabular}




\section{A. HEMPSTEAD COUNTY 09S23W33CDA1}

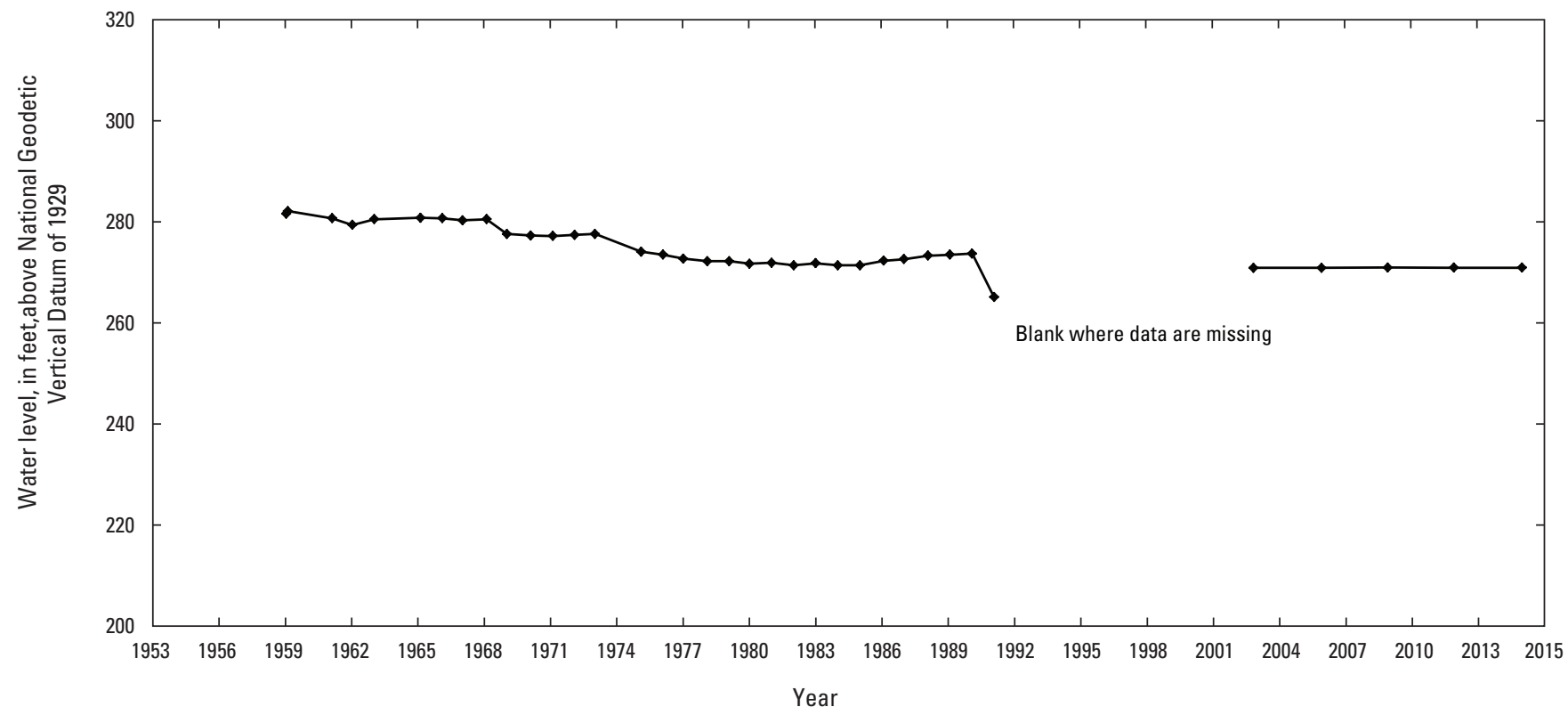

B. HEMPSTEAD COUNTY 09S26W18CBB1

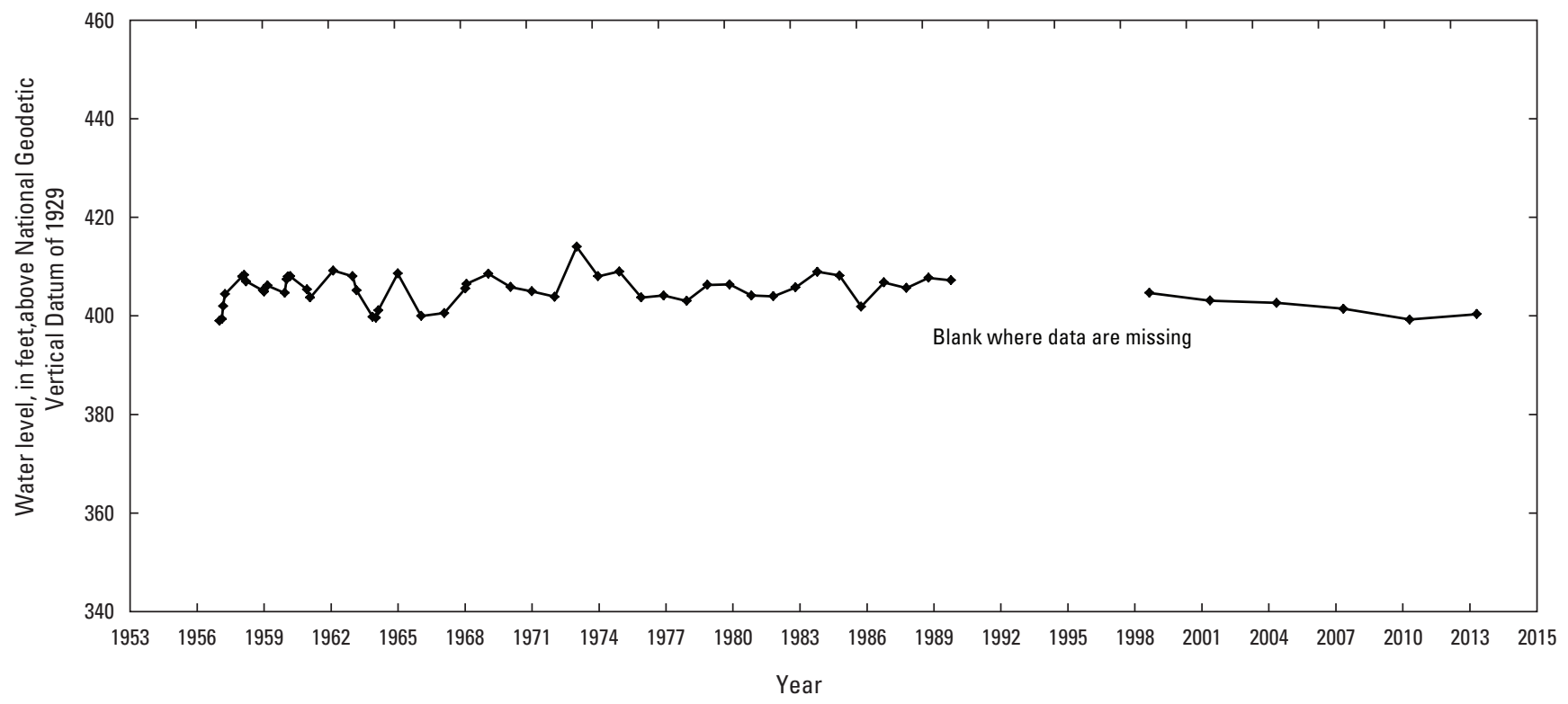

Figure 15. Water-level hydrographs for selected wells completed in the Tokio aquifer in southwestern Arkansas. Blank where data are missing. 


\section{HEMPSTEAD COUNTY 12S24W06DAD1}

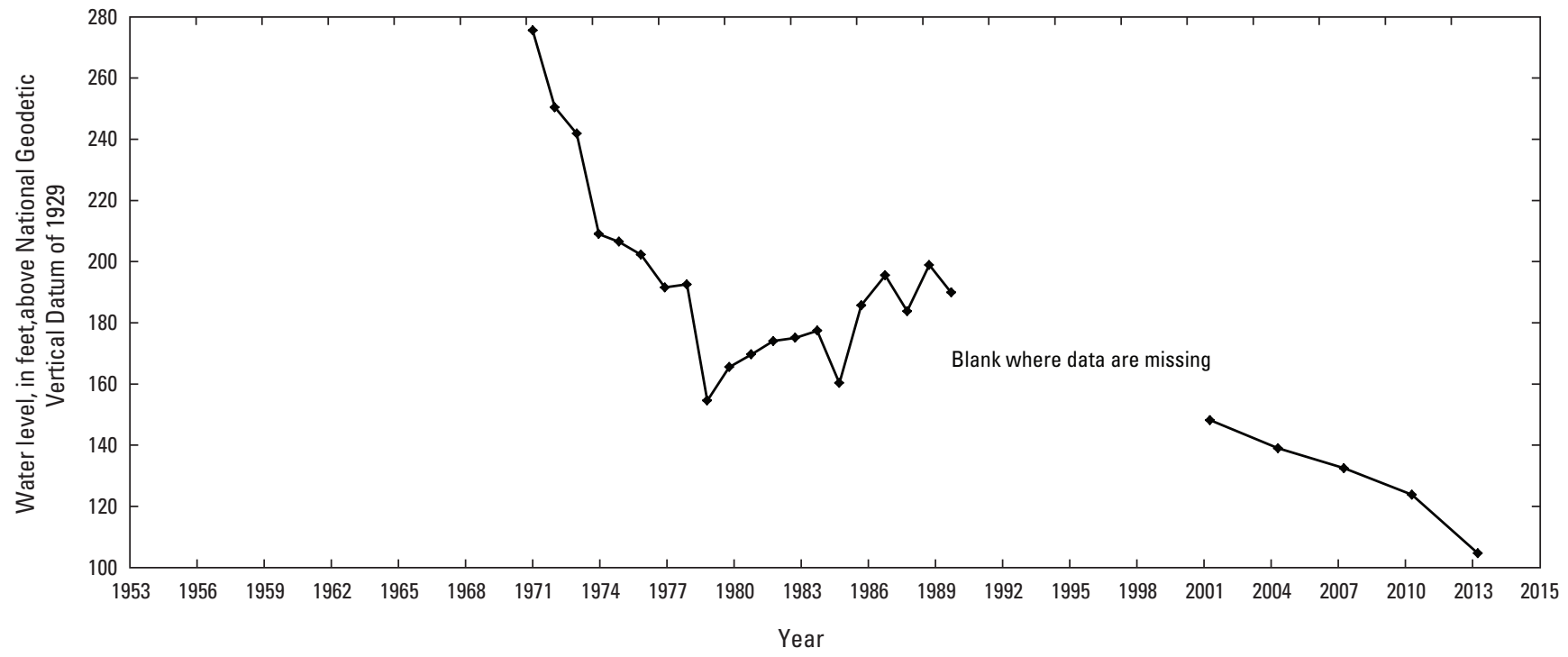

Figure 15. Water-level hydrographs for selected wells completed in the Tokio aquifer in southwestern Arkansas. Blank where data are missing.-Continued

\section{Summary}

A water-level survey conducted in 2014-15 in the Nacatoch and Tokio aquifers indicates that water levels in both aquifers have changed over time. Short-term data (2008 compared to 2014-15 data) indicate that water levels increased in over half of the measured wells in the Nacatoch aquifer; however, long-term trends show an overall decrease in water levels. In the Tokio aquifer, short-term data indicate a decline in water levels measured in wells since 2008; however, long-term data from wells showed both decreasing and increasing trends. When compared to previous potentiometric surfaces for both aquifers in 2013, regional groundwater flow direction has not changed. However, both aquifers had cones of depression near the city of Hope that are likely a result of groundwater withdrawals for agricultural, domestic, industrial, and public use, and these cones have altered the local flow direction. Long-term monitoring of groundwater is important to water resource managers because the data can be used to identify sources of waterlevel fluctuations that result from changes in withdrawal, climate, and interaction with overlying and underlying rock units.

\section{References Cited}

Bodansky, Eugene, Gribov, Alexander, and Pilouk, Morakot, 2002, Smoothing and compression of lines obtained by raster-to-vector conversion: Lecture Notes in Computer Science, v. 2390, Springer Publishing Co., p. 256-265. [Also available at http://link.springer.com/chapter/10.1007 \%2F3-540-45868-9_22.]

Boswell, E.H., Moore, G.K., MacCary, L.M., and others, 1965, Cretaceous aquifers in the Mississippi Embayment: U.S. Geological Survey Professional Paper 448-C, 37 p. [Also available at http://pubs.usgs.gov/pp/0448c/report.pdf.]

Counts, H.B., 1957, Ground-water resources of parts of Lonoke, Prairie, and White Counties, Arkansas: Arkansas Geological and Conservation Commission Water Resources Circular 5, 65 p. [Also available at http://www.geology. ar.gov/pdf/Water\%20Resources\%20Circular\%205_v.pdf.]

Counts, H.B., Tait, D.B., Klein, Howard, and Billingsley, G.A., 1955, Ground-water resources in a part of southwestern Arkansas: U.S. Geological Survey Water Resources Circular No. 2, 35 p. 
Cunningham, W.L., and Schalk, C.W., comps., 2011, Groundwater technical procedures of the U.S. Geological Survey: U.S. Geological Survey Techniques and Methods 1-A1, 151 p. [Available at http://pubs.usgs.gov/tm/1a1/.]

Cushing, E.M., Boswell, E.H., and Hosman, R.L., 1964, General geology of the Mississippi embayment: U.S. Geological Survey Profession Paper 448-B, 32 p. [Also available at http://pubs.usgs.gov/pp/0448b/report.pdf.]

Esri, 2011, ArcGIS desktop_-Release 10: Redlands, California, Environmental Systems Research Institute.

Fenneman, N.M., and Johnson, D.W., 1946: Physiographic divisions of the conterminous U.S.: U.S. Geological Survey, scale 1:7,000,000, accessed September 22, 2015, at http:// water.usgs.gov/GIS/metadata/usgswrd/XML/physio.xml.

Halberg, H.N., and Stephens, J.W., 1966, Use of water in Arkansas, 1965: Arkansas Geological Commission Water Resources Summary Number 5, 12 p. [Also available at http://www.geology.ar.gov/water_summaries/wrs5.htm.]

Hart, R.M., and Clark, B.R., 2008, Geophysical log database for the Mississippi Embayment Regional Aquifer Study (MERAS): U.S. Geological Survey Scientific Investigations Report 2008-5192, 8 p. [Also available at http://pubs.usgs. gov/sir/2008/5192/.]

Hart, R.M., Clark, B.R., and Bolyard, S.E., 2008, Digital surfaces and thicknesses of selected hydrogeologic units within the Mississippi Embayment Regional Aquifer Study (MERAS): U.S. Geological Survey Scientific Investigations Report 2008-5098, 8 p. [Also available at http://pubs.usgs. gov/sir/2008/5098/.]

Helsel, D.R., and R.M. Hirsch, 2002. Statistical methods in water resources: U.S. Geological Survey Techniques of Water Resources Investigations, book 4, chap. A3, 522 p., accessed March 16, 2015, at http://pubs.usgs.gov/twri/ twri4a3/.

Holland, T.W., 1987, Use of water in Arkansas, 1985: Arkansas Geological Commission Water Resources Summary Number 16, 27 p. [Also available at http://www. geology.ar.gov/water_summaries/wrs16htm.]

Holland, T.W., 1993, Use of water in Arkansas, 1990: U.S. Geological Survey Open-File Report 93-48, pamphlet. [Also available at http://pubs.er.usgs.gov/publication/ ofr9348.]

Holland, T.W., 1999, Water use in Arkansas, 1995: U.S. Geological Survey Open-File Report 99-188, 1 sheet. [Also available at http://pubs.er.usgs.gov/publication/ ofr99188.]
Holland, T.W., 2004, Estimated water use in Arkansas, 2000: U.S. Geological Survey Scientific Investigations Report 2004-5230, 31 p. [Also available at http://pubs.er.usgs.gov/ publication/sir20045230.]

Holland, T.W., 2007, Estimated water use in Arkansas, 2005: U.S. Geological Survey Scientific Investigations Report 2004-5230, 31 p. [Also available at http://pubs.usgs.gov/ $\operatorname{sir} / 2007 / 5241 /$.

Holland, T.W., and Ludwig, A.H., 1981, Use of water in Arkansas, 1980: Arkansas Geological Commission Water Resources Summary Number 14, 29 p. [Also available at http://www.geology.arkansas.gov/water_summaries/wrs14. htm.]

Kresse, T.M., Hays, P.D., Merriman, K.R., Gillip, J.A., Fugitt, D. Todd, Spellman, J.L., Nottmeier, A.M., Westerman, D.A., Blackstock, J.M., and Battreal, J.L., 2014, Aquifers of Arkansas_-Protection, management, and hydrologic and geochemical characteristics of groundwater resources in Arkansas: U.S. Geological Survey Scientific Investigations Report 2014-5149, 334 p. [Also available at http://pubs. usgs.gov/sir/2014/5149/.]

Ludwig, A.H., 1972, Water resources of Hempstead, Lafayette, Little River, Miller, and Nevada Counties, Arkansas: U.S. Geological Survey Water-Supply Paper 1998, 41 p. [Also available at http://pubs.er.usgs.gov/publication/wsp1998.]

Payne, J.N., 1972, Hydrologic significance of lithofacies of the Cane River Formation or equivalents of Arkansas, Louisiana, Mississippi, and Texas: U.S. Geological Survey Professional Paper 569-C, 17 p. [Also available at http:// pubs.er.usgs.gov/publication/pp569C.]

Petersen, J.C., Broom, M.E., and Bush, W.V., 1985, Geohydrologic units of the Gulf Coastal Plain in Arkansas: U.S. Geological Survey Water-Resources Investigations Report 85-4116, 20 p. [Also available at http://pubs.usgs. gov/wri/1985/4116/report.pdf.]

Plebuch, R.O., and Hines, M.S., 1969, Water resources of Clark, Cleveland, and Dallas Counties, Arkansas: U.S. Geological Survey Water-Supply Paper 1879-A, 32 p. [Also available at http://pubs.er.usgs.gov/publication/wsp1879A.]

Pugh, A.L., and Holland, T.W., 2015, Estimated water use in Arkansas, 2010: U.S. Geological Survey Scientific Investigations Report 2015-5062, 33 p., accessed September 26, 2015, at http://dx.doi.org/10.3133/ sir20155062.

Renken, R.A., 1998, Ground water atlas of the United States-Segment 5, Arkansas, Louisiana, Mississippi: U.S. Geological Survey Hydrologic Atlas 730-F, 28 p. [Also available at http://pubs.er.usgs.gov/publication/ha730F.] 
Rodgers, K.D., 2017, Potentiometric contours for the Nacatoch aquifer of northeastern and southwestern Arkansas and the Tokio aquifer of southwestern Arkansas, 2014-15: U.S.

Geological Survey data release at https://www.sciencebase. gov/catalog/item/588a4e5ce4b0ba3b075e978f.

Schrader, T.P., and Rodgers, K.D., 2013, Water levels in the aquifers of the Nacatoch Sand of southwestern and northeastern Arkansas and the Tokio Formation of southwestern Arkansas, February-March 2011: U.S. Geological Survey Scientific Investigations Report 20135130, 21 p., accessed March, 16, 2015, at http://pubs.usgs. gov/sir/2013/5130/.
Schrader. T.P., and Scheiderer, R.M., 2004, Status of water levels in aquifers in the Nacatoch Sand of southwestern and northeastern Arkansas and the Tokio Formation of southwestern Arkansas, 2002: U.S. Geological Survey Water-Resources Investigations Report 03-4284, 24 p. [Also available at http://pubs.usgs.gov/wri/wri03-4284/ WRIR03-4284.pdf.]

U.S. Geological Survey, 2016, National Water Information System-Web interface, accessed December 16, 2014, at http://dx.doi.org/10.5066/F7P55KJN.

For more information about this publication, contact

Lower Mississippi Gulf Water Science Center

For additional information visit

https://www.usgs.gov/centers/lmg-water

Publishing support provided by

Lafayette Publishing Service Center 



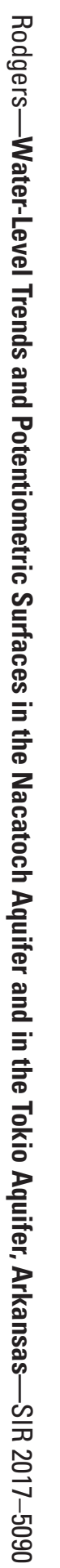

